\title{
Demographics and Movements of Least Terns and Piping Plovers in the Central Platte River Valley, Nebraska
}

Open-File Report 2016-1061 



\section{Demographics and Movements of Least Terns and Piping Plovers in the Central Platte River Valley, Nebraska}

By Erin A. Roche, Mark H. Sherfy, Megan M. Ring, Terry L. Shaffer, Michael J. Anteau, and Jennifer H. Stucker

Open-File Report 2016-1061 


\title{
U.S. Department of the Interior SALLY JEWELL, Secretary
}

\section{U.S. Geological Survey Suzette M. Kimball, Director}

\author{
U.S. Geological Survey, Reston, Virginia: 2016
}

For more information on the USGS - the Federal source for science about the Earth, its natural and living resources, natural hazards, and the environment—visit http://www.usgs.gov or call 1-888-ASK-USGS.

For an overview of USGS information products, including maps, imagery, and publications, visit http://store.usgs.gov.

Any use of trade, firm, or product names is for descriptive purposes only and does not imply endorsement by the U.S. Government.

Although this information product, for the most part, is in the public domain, it also may contain copyrighted materials as noted in the text. Permission to reproduce copyrighted items must be secured from the copyright owner.

Suggested citation:

Roche, E.A., Sherfy, M.H., Ring, M.M., Shaffer, T.L., Anteau, M.J., and Stucker, J.H., 2016, Demographics and movements of least terns and piping plovers in the Central Platte River Valley, Nebraska: U.S. Geological Survey Open-File Report 2016-1061, 27 p., http://dx.doi.org/10.3133/ofr20161061.

ISSN 2331-1258 (online) 


\section{Contents}

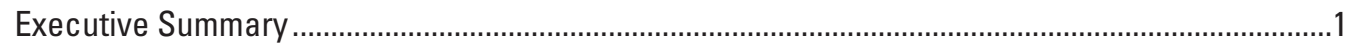

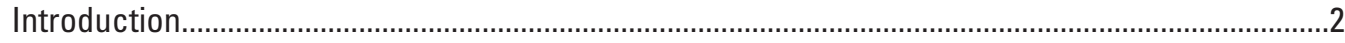

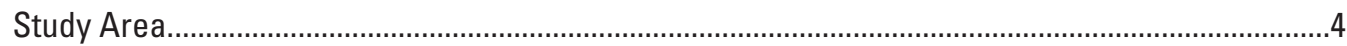

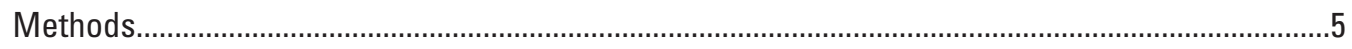

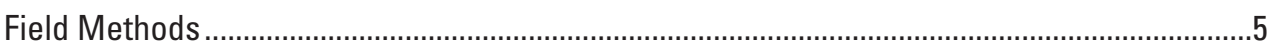

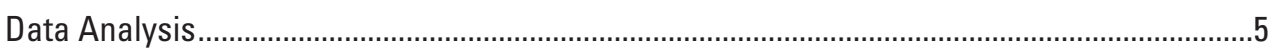

Reproductive Success—Nest Survival Rates ..........................................................5

Reproductive Success_Chick Survival to Fledging Age ..............................................

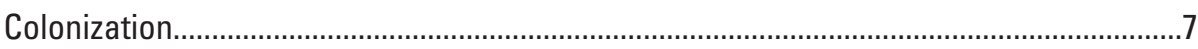

Apparent Survival of Juveniles and Nesting Adults ......................................................

Dispersal and Philopatry ............................................................................................

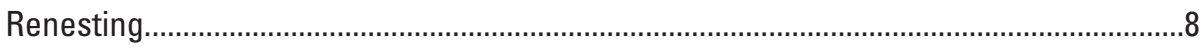

Migratory, Winter, and other non-Central Platte River Valley Resightings of Piping Plovers .....................................................................................................

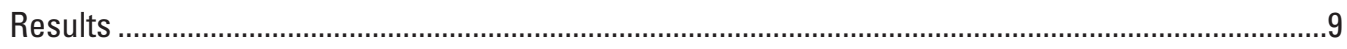

Reproductive Success_Nest Survival Rates ................................................................

Reproductive Success—Chick Survival to Fledging Age ......................................................

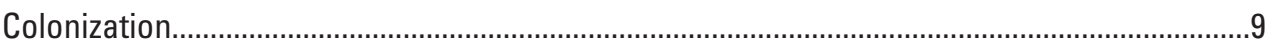

Apparent Survival of Juveniles and Nesting Adults ...........................................................17

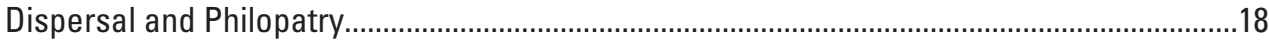

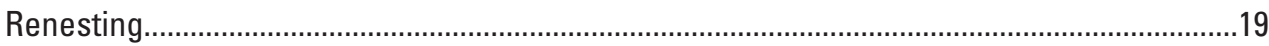

Migratory, Winter, and other non-Central Platte River Valley Resightings of

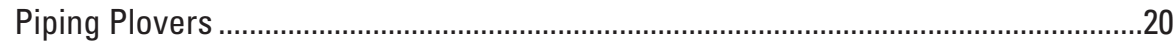

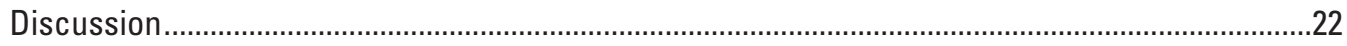

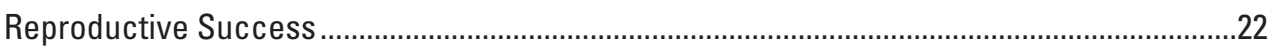

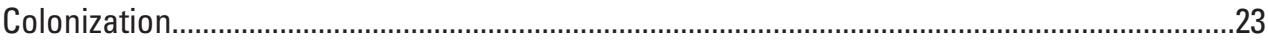

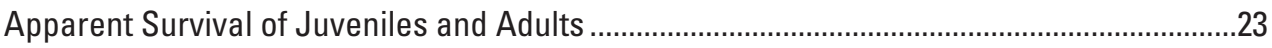

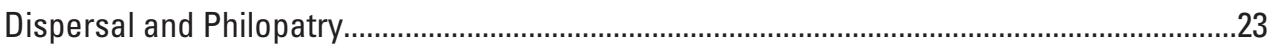

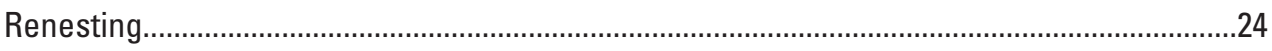

Migratory, Winter, and other non-Central Platte River Valley Resightings of

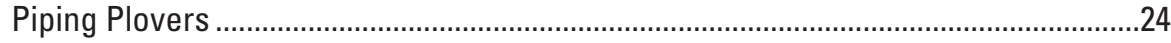

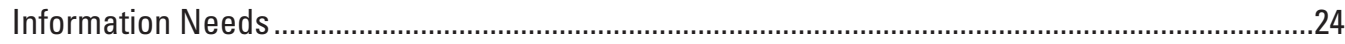

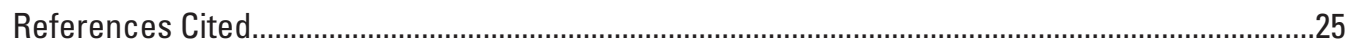




\section{Figures}

1. Map showing Central Platte River Valley study area during 2009-14 .3

2. Graph showing cumulative nest survival (21 days) rates of least tern nests in the Central Platte River Valley, 2009-14.

3. Graph showing cumulative nest survival rates (21 days) based on nest site age class for least tern nests initiated in the Central Platte River Valley, 2009-14.

4. Graph showing cumulative nest survival rates of piping plover nests ( 35 days) in the Central Platte River Valley, 2009-14...

5. Graph showing cumulative survival rates of least tern chicks to fledging age (16 days) in the Central Platte River Valley, 2009-14.

6. Graph showing cumulative survival rates of least tern chicks to fledging age (16 days) based on site age class at which chicks were hatched in the Central Platte River Valley, 2009-14 ...

7. Graph showing cumulative survival rates of piping plover chicks to fledging age (21 days) in the Central Platte River Valley, 2009-14..

8. Map showing wintering ground observations of piping plovers uniquely marked in the Central Platte River Valley, 2009-14

\section{Tables}

1. Central Platte River Valley least tern and piping plover nesting sites included in analyses of reproductive success, dispersal, renesting frequency, and colonization

2. Number of successful and failed least tern nests on the Central Platte River Valley during 2009-14 included in the nest survival analysis.

3. Nest survival models used to estimate daily nest survival rates for least tern nests initiated in the Central Platte River Valley during 2009-14.

4. Nest survival models used to estimate daily nest survival rates for least tern nests initiated on created sites in the Central Platte River Valley during 2009-14

5. Number of successful and failed piping plover nests in the Central Platte River Valley during 2009-14 included in the nest survival analysis.

6. Nest survival models used to estimate daily nest survival rates for piping plover nests initiated in the Central Platte River Valley during 2009-14

7. Nest survival models used to estimate daily nest survival rates or piping plover nests initiated on sites created in the Central Platte River Valley during 2009-14..........13

8. Number of least terns and piping plovers banded by age and year in the Central Platte River Valley (2009-14)

9. Cormack-Jolly-Seber survival models used to estimate daily survival rates for least tern chicks hatched in the Central Platte River Valley during 2009-14.

10. Cormack-Jolly-Seber survival models used to estimate daily apparent survival rates for piping plover chicks hatched in the Central Platte River Valley during 2009-14

11. Summary of least tern nests found at sites created in the Central Platte River Valley during 2009-14 by site age in years (first year through fifth year) and site age class (first year available and after first year available) used in linear and logistic regression analyses. 
12. Summary of uniquely marked least terns resighted or recaptured on sites created in the Central Platte River Valley during 2009-14 by site age in years, site age class, and tern age class used in linear and logistic regression analyses.

13. Summary of piping plover nests found at sites created in the Central Platte River Valley during 2009-14 by site age in years and site age class used in linear and logistic regression analyses

14. Summary of uniquely marked piping plovers resighted or recaptured at sites created in the Central Platte River Valley during 2009-14 by site age in years, site age class, and plover age class used in linear and logistic regression analyses.

15. Central Platte River Valley hatch sites and sites where a first nesting attempt was observed for four uniquely identifiable least terns marked and resighted/recapture during 2009-14...

16. Dispersal of uniquely marked least terns in the Central Platte River Valley during 2009-14

17. Central Platte River Valley hatch sites and sites where a first nesting attempt was observed for uniquely identifiable piping plovers marked and resighted/recapture during 2009-14.....

18. Dispersal of uniquely marked piping plovers in the Central Platte River Valley during 2009-14...

19. Number of successful, failed, and unknown fate nests and renests attended by at least one uniquely identifiable least tern in the Central Platte River Valley during 2009-14

20. Number of successful, failed, and unknown fate nests and renests attended by at least one uniquely identifiable piping plover in the Central Platte River Valley during 2009-14

21. Breeding locations for uniquely identifiable adult piping plovers originally banded in the Central Platte River Valley.

\section{Conversion Factors}

International System of Units to Inch/Pound

\begin{tabular}{lcc}
\hline Multiply & By & To obtain \\
\hline & Length & \\
\hline kilometer $(\mathrm{km})$ & 0.6214 & mile $(\mathrm{mi})$ \\
\hline
\end{tabular}

Temperature in degrees Celsius $\left({ }^{\circ} \mathrm{C}\right)$ may be converted to degrees Fahrenheit $\left({ }^{\circ} \mathrm{F}\right)$ as

$$
{ }^{\circ} \mathrm{F}=\left(1.8 \times{ }^{\circ} \mathrm{C}\right)+32 .
$$

Temperature in degrees Fahrenheit $\left({ }^{\circ} \mathrm{F}\right)$ may be converted to degrees Celsius $\left({ }^{\circ} \mathrm{C}\right)$ as

$$
{ }^{\circ} \mathrm{C}=\left({ }^{\circ} \mathrm{F}-32\right) / 1.8 .
$$




\section{Abbreviations}

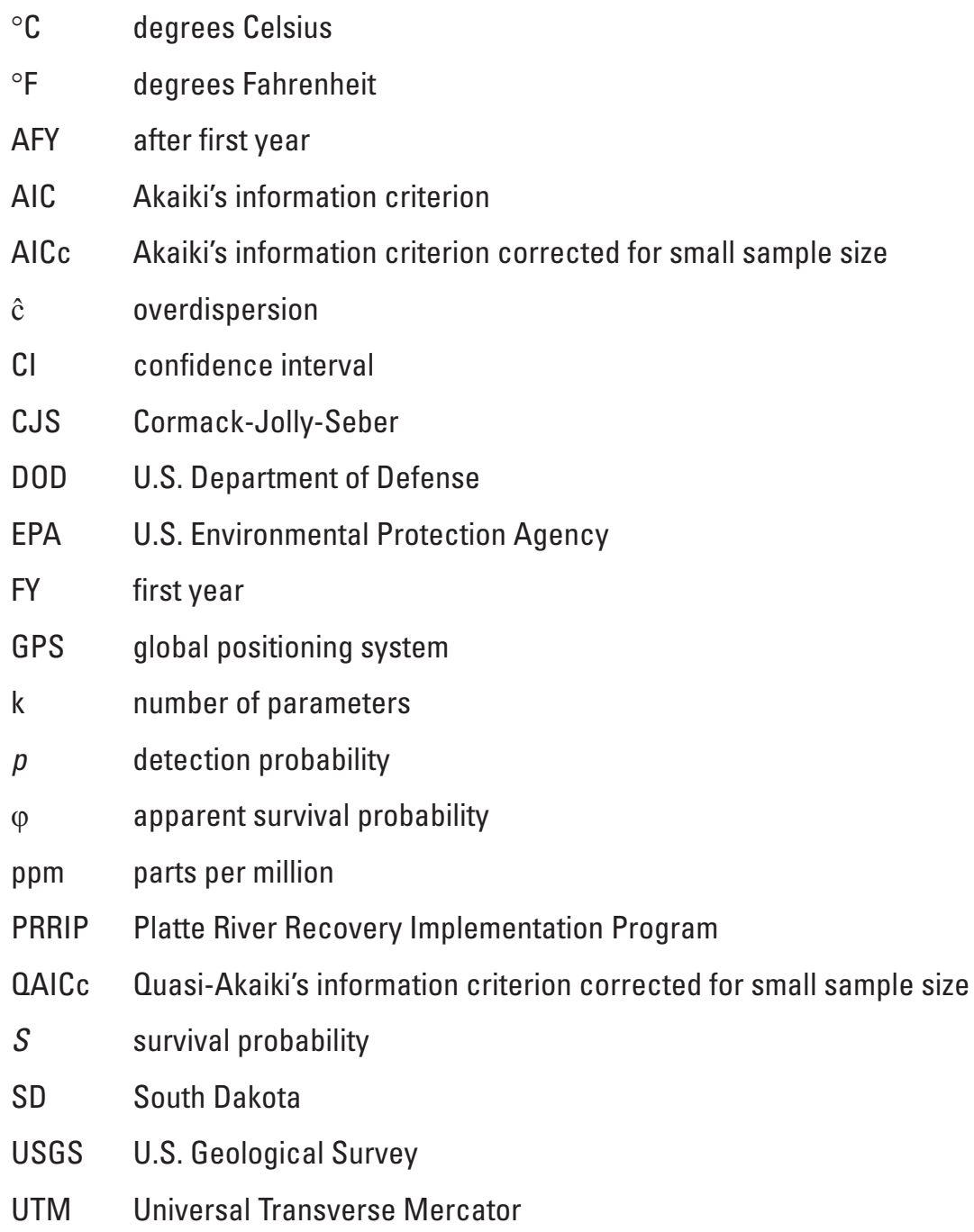




\title{
Demographics and Movements of Least Terns and Piping Plovers in the Central Platte River Valley, Nebraska
}

\author{
By Erin A. Roche, Mark H. Sherfy, Megan M. Ring, Terry L. Shaffer, Michael J. Anteau, and \\ Jennifer H. Stucker
}

\section{Executive Summary}

The Central Platte River Valley provides breeding habitat for a variety of migratory birds, including federally endangered interior least terns (Sternula antillarum; least tern) and threatened piping plovers (Charadrius melodus). Since 2009, researchers have collected demographic data on both species that span their lifecycle (that is, from egg laying through survival of adults). Demographic data were used to estimate vital rates (for example, nest survival, chick survival, and so on) for both species and assess how these vital rates were related to type and age of nesting habitat. Nest survival of both species was unrelated to the age of the site a nest was initiated on. Piping plover chick survival to fledging age was not related to the age of the site it was hatched at, however, the probability of a least tern chick surviving to fledging was higher at older sites. In general there were fewer piping plover nests than least tern nests found at sites created through either the physical construction of a new site or new vegetation management regimes, during 2009-14.

Mean daily least tern nest survival was 0.9742 (95-percent confidence interval [CI]: 0.9692-0.9783) and cumulative nest survival was 0.59 (95-percent CI: $0.53-0.65$ ). Mean daily least tern chick survival was 0.9602 (95-percent CI: 0.9515-0.9673) and cumulative survival to fledging was 0.54 (95-percent $\mathrm{CI}=0.48-0.61$ ). Annual apparent survival rates were estimated at 0.42 (95-percent $\mathrm{CI}=0.22-0.64$ ) for adult least terns nesting in the Central Platte River Valley and an apparent survival rate of 0.14 (95-pecent $\mathrm{CI}=0.04-0.41$ ) for juvenile least terns. The number of least tern nests present at sites created during 2009-14 was associated with the age of the site; more least tern nests were associated with older sites. During 2009-14, there were four (less than 1 percent of all chicks marked) least tern chicks hatched from the Central Platte River Valley that were subsequently captured on nests as adults. Two of these least terns returned to nest at the same site they had hatched from. Ten instances were documented in which an adult least tern could either switch to nest at a new location or remain at the previous location with the onset of a new year. In five (50 percent) of these instances, least terns returned to nest on the site where they had nested in a previous year.

For piping plovers, mean daily apparent nest survival was 0.9880 (95-pecent CI: 0.9836-0.9912) and cumulative nest survival was 0.66 (95-pecent CI: 0.57-0.74). Mean daily piping plover chick survival was 0.9621 (95-pecent CI: $0.9514-0.9706$ ) and cumulative survival to fledging was 0.46 (95-pecent $\mathrm{CI}=0.37-0.56$ ). The annual apparent survival estimate for adult piping plovers nesting in the Central Platte River Valley was 0.76 (95-pecent $\mathrm{CI}=0.65-0.85)$ and was 0.20 (95-pecent $\mathrm{CI}=0.14-0.29$ ) for juvenile piping plovers. The number of piping plover nests present at sites created through either the physical construction of a new site or new vegetation management regimes was also associated with site age, with more piping plover nests associated with older sites; however, in general there were fewer piping plover nests found at created sites than least tern nests. Only first-year adult piping plovers were observed on sites in the first year of availability, whereas older sites had a higher proportion of after-first-year adult piping plovers than first-year adult piping plovers. Twelve piping plover chicks (approximately 3 percent of all chicks marked) hatched from the Central Platte River Valley and were subsequently documented on nests as adults. All piping plovers returned to nest on different sites from the one on which they hatched. A total of 45 instances were documented in which an adult plover could either switch to nest at a new location or remain at the previous location with the onset of a new year. In 39 instances ( 87 percent), the adult nested on the same site as its prior documented nesting attempt and in 6 of these instances the adult switched to a new nesting location between years. There were 13 of 75 uniquely identifiable piping plovers observed to renest (that is, initiate more than one nest in a season) during 2009-14; no renests were observed among uniquely identifiable least terns. In all but one case, piping plover renests were found at the same site as the first nest initiated that season. For birds that renested, the mean initiation date of the first nest was May 6 and the mean initiation date of the second nest was June 8. On average, renests were initiated 7.5 days plus or minus 7.3 (SD [standard deviation]) following the date the initial nesting attempt was 'fated' (considered either failed or hatched). 


\section{Introduction}

The Central Platte River Valley is a resource area of continental significance to migratory birds. Habitat and food provided in this area are important for migration and successful breeding in many species, including waterfowl, shorebirds, and passerines (Sherfy and others, 2012a). The Central Platte River Valley also provides breeding habitat for a variety of migratory birds, including federally endangered interior least terns (Sternula antillarum; least tern) and threatened piping plovers (Charadrius melodus; Faanes, 1983). Both of these species co-occur on many large mid-continent river systems where they nest in loosely organized mixed colonies (Thompson and others, 1997; Haig and Elliott-Smith, 2004).

At the onset of settlement in the mid-1800s, the Platte River exhibited a wide, mostly unvegetated, braided planform with an average width on the order of 3,800 ft (Williams, 1978). Water development began in tandem with settlement and the Platte River is now (2015) one of the most heavily regulated rivers in the world with more than seven thousand diversion rights and seven million acre-ft of reservoir storage (Simons and Associates Inc., 2000). The Platte River has narrowed substantially since the mid-1800s through the expansion of cottonwood forest into previously active parts of the channel (Williams, 1978; Eschner and others, 1983; Johnson, 1994; Simons and Associates, 2000; Murphy and others, 2004). Most river channel narrowing took place during the 1940s and 1950s with channel area stabilizing by the 1980s (Johnson, 1994). Woody vegetation expansion in the Platte River has been studied extensively with most investigators concluding that alterations in hydrology caused by water development were the primary driver of narrowing (Currier, 1997). Alternative hypotheses of specific mechanisms of narrowing include a reduction in peak flow magnitudes and associated ability to scour vegetation (Williams, 1978; Murphy and others, 2004), a reduction in flow during the cottonwood germination period leading to increased recruitment (Johnson, 1994; Simons and Associates Inc., 2000), and a decrease in desiccation mortality of seedlings in summer as the river transitioned from ephemeral to perennial because of irrigation return flows (Schumm, 2005).

The first records of least terns and piping plovers in the Central Platte River Valley date to the 1940s, after the bulk of water development had already taken place and the channel was narrowing (Wycoff, 1960). Accordingly, it is not possible to infer a decline in habitat suitability or corresponding declines in species use or productivity with historical timeframes from the data that are available. The first recorded least tern observations in the Central Platte River Valley was made near Lexington, Nebraska (fig. 1). Nesting was observed on a low sandbar in the channel, high in-channel islands created by sand mining, and at adjacent sandpits (Wycoff, 1960). No information on piping plover use and productivity is currently (2015) available before the onset of systematic survey efforts in 1979 (Pitts, 1988). Since 1979, approximately 88 percent of least tern nests and 75 percent of piping plover nests in the Central Platte River Valley have been observed on sandpits
(Faanes, 1983; Sidle and Kirsch, 1993; Kirsch, 1996; Jenniges and Plettner, 2008; Sherfy and others, 2012a; Platte River Recovery Implementation Program, 2014). Approximately 9 percent of least tern nests and 18 percent of piping plover nests have been observed on constructed or managed in-channel sandbar habitat and 3 percent of least tern nests and 7 percent of piping plover nests have been observed on naturally formed sandbars (Executive Director's Office, 2015).

In 2009, the Platte River Recovery Implementation Program (hereafter 'PRRIP') began constructing and managing additional off-channel (sandpits) and a few in-channel (midchannel sandbars) nesting sites to add to the existing habitat that was mechanically created or managed by other conservation entities. The goal of this work was to improve the foraging and nesting habitat conditions for piping plovers and least terns and thus facilitate population growth and continued viability. At the same time, researchers were collecting site-specific data on nest success, and chicks and adults of both species were the subject of a mark-recapture program aimed at estimating survival and movement. This work has produced demographic data for both species that span the entire lifecycle (that is, from egg laying through survival of adults). It also presents a unique opportunity as conditions are ideal to investigate what demographic characteristics contribute to a shift in breeding population distribution throughout the Central Platte River Valley.

To this end, the demographic data collected during 2009-14 were compiled and, where possible, used to assess how the vital rates (for example, nest survival, chick survival, and so on) of both species were related to type and age of nesting habitat. The analysis focused on addressing the following five objectives:

I. Reproductive Success - Quantify abundance, distribution, reproductive success and reproductive habitat parameters in the study area.

II. Colonization-Quantify colonization rate of nesting habitat by local adults compared to immigrant adults.

III. Adult Survival and Recruitment-Quantify survival rates of after-hatch-year nesting adults and hatch year adults (that is, survival from banding as a chick to first year as an adult).

IV. Dispersal-Quantify dispersal of breeding adults between units of nesting habitat.

V. Renesting - Quantify frequency, timing and location of renesting attempts by adults with failed nests or broods of chicks.

The purpose and scope of this report is to summarize the least tern and piping plover demographic data relative to these objectives and to place our results in the context of previous research on both species. At present (2015), insufficient sample sizes prevent a definitive assessment of how population demography corresponds to habitat type; however, the results presented in this report summarize the patterns observed to date and shed light on future research avenues. 


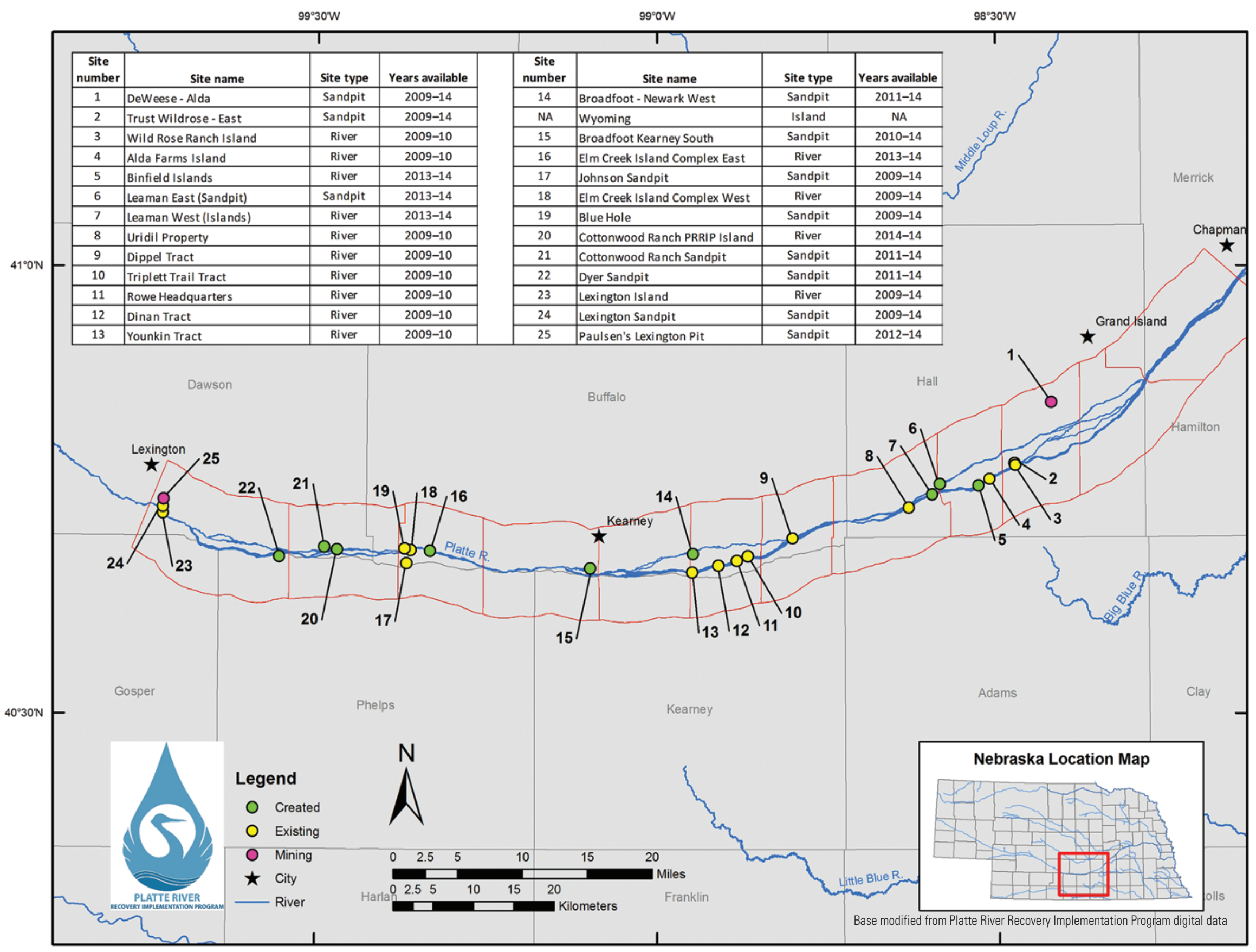

Figure 1. Central Platte River Valley study area during 2009-14. 


\section{Study Area}

This study includes the population of least terns and piping plovers that nest within the Central Platte River Valley beginning at the junction of U.S. Highway 283 and Interstate 80 near Lexington, Nebraska, and extending eastward to Chapman, Nebraska (fig. 1). The study area includes approximately 90 miles of the Platte River and sandpits within 3.5 miles of the main channel or within 2 miles of a side channel if the side channel extends beyond 3.5 miles of the main channel. The 2009-10 field efforts for the foraging ecology study were focused on sites where the highest numbers of least tern and piping plover nests had previously been reported (Sherfy and others, 2012a). Other potential sites were sought for inclusion each year, but the foraging ecology study was limited to 6 preselected focal areas. When research efforts were extended to 2011-14, additional sites were added as they became available with acquisition or management action (table 1).

Table 1. Central Platte River Valley least tern and piping plover nesting sites included in analyses of reproductive success, dispersal, renesting frequency, and colonization.

['Site type' indicates whether the site is located along the Platte River or an off-river sandpit, 'First year available' indicates the year (when known) that the site first had nesting habitat available. All sites were located in Nebraska.]

\begin{tabular}{|c|c|c|}
\hline Site name & Site type & First year available \\
\hline DeWeese-Alda & Sandpit & $<2001$ \\
\hline Trust Wildrose-East & Sandpit & 2008 \\
\hline Wild Rose Ranch Island & River & 2008 \\
\hline Alda Farms Island & River & $<2001$ \\
\hline Binfield Islands & River & 2014 \\
\hline Leaman East (Sandpit) & Sandpit & 2013 \\
\hline Leaman West (Islands) & River & 2013 \\
\hline Uridil Property & River & 2009 \\
\hline Dippel Tract & River & 2007 \\
\hline Triplett Trail Tract & River & 2008 \\
\hline Rowe Headquarters & River & 2008 \\
\hline Dinan Tract & River & 2007 \\
\hline Younkin Tract & River & 2009 \\
\hline Broadfoot-Newark West & Sandpit & 2011 \\
\hline Wyoming Property & River & NA \\
\hline Broadfoot-Kearney South & Sandpit & 2010 \\
\hline Elm Creek Island Complex East & River & 2013 \\
\hline Johnson Sandpit & Sandpit & $<2001$ \\
\hline Elm Creek Island Complex West & River & $<2001$ \\
\hline Blue Hole & Sandpit & $<2001$ \\
\hline Cottonwood Ranch PRRIP Island & River & 2014 \\
\hline Cottonwood Ranch Sandpit & Sandpit & 2011 \\
\hline Dyer Sandpit & Sandpit & 2011 \\
\hline Lexington Island & River & $<2001$ \\
\hline Lexington Sandpit & Sandpit & $<2001$ \\
\hline Paulsen's Lexington Pit & Sandpit & 2012 \\
\hline
\end{tabular}




\section{Methods}

\section{Field Methods}

Surveys of sites with nests or broods took place at least twice per week. All sites PRRIP considered suitable bare-sand nesting habitat in the surveyed area were included (fig. 1). A crew of 3 to 5 technicians systematically searched for nests within each area approximately every 2 to 3 days from May 1 to mid-August, during 2009-14. A systematic search consisted of the crew members spaced 5 to 10 meters apart walking parallel to each other in a zig-zag pattern as they scanned the ground for nests. A nest was defined as a scrape containing one or more eggs or eggshell fragments. Nests also occasionally were found incidentally when technicians visited sites for other purposes. Nest locations were recorded with Global Positioning System (GPS) units and incubation stage was estimated by floating one or more eggs on the day of nest discovery. Nests were revisited every 2 to 3 days, except near the expected hatch date then they were revisited daily to determine nest fate. Nests were considered successful if at least one egg hatched. Nest fate was determined from evidence at the nest and recorded as follows: successful, probable successful, probable failure, failure, or fate unknown.

Adult least terns and piping plovers were trapped on nests using hoop nets or walk in traps (Hill and Talent, 1990). Trapping took place early or late in the day or when air temperature ranged between 15 degrees Celsius $\left({ }^{\circ} \mathrm{C}\right)$ (60 degrees Fahrenheit $\left.\left[{ }^{\circ} \mathrm{F}\right]\right)$ and $32{ }^{\circ} \mathrm{C}\left(90^{\circ} \mathrm{F}\right)$, wind was minimal or not disrupting nests, and there was no precipitation. Trapping took place at least 48 hours after the onset of incubation, but before pipping. Trapping attempts were aborted if they exceeded 30 minutes as measured from the departure of the bird from the nest through completion of the trap attempt. Before trap deployment, eggs from targeted nests were exchanged with artificial eggs to reduce potential risk of injury; real eggs were stored in small plastic containers cushioned with synthetic batting. Once captured, birds were moved to a nearby area away from the colony and other nesting birds. Birds were weighed with a spring scale. Each adult piping plover was banded with a size 1A numbered U.S. Geological Survey (USGS) aluminum band on the upper leg, a light blue Darvic (Avinet, Inc., Dryden, New York) plastic short flag on the opposite upper leg, and as many as 2 Darvic color bands on each of the lower legs (total of 4 color bands). The banding approach for least tern adults was adjusted partway through the study. During 2009-12, each adult tern was banded with a size 1A numbered USGS stainless steel band on the lower leg and as many as three celluloid bands (size XCL) on the upper leg (two bands per leg). The use of celluloid bands was discontinued in 2013 because of band retention issues; instead each adult least tern was banded with a size 1 A numbered USGS stainless steel band on 1 lower leg and a 2-character Darvic alpha-numeric band on the other lower leg. Crews conducting surveys of nesting habitats carried spotting scopes and recorded band combinations of any birds that were resighted. Adults were associated with nests based on behavioral observations during resighting as well as capture records of previously banded birds.

Crews attempted to mark every least tern and piping plover chick encountered. Because nests were visited more frequently near the expected hatch date, chicks were typically located in or near the nest bowl and were thus able to be banded at a young age. In most cases, this allowed the accurate assignment of each chick to a nest. When unbanded chicks were first found outside a nest bowl, no assumptions were made about which nest they had hatched from, and their nest origin was recorded as unknown. Each piping plover chick was initially banded with a light blue flag and USGS size 1A aluminum metal band on the opposite upper legs (tibia). Additionally, 4 colored bands were placed in various positions on the lower legs (tarsometatarsus), positioned to create a unique color combination for each bird. Crews attempted to mark each least tern chick as soon after hatching as possible, and adjusted the banding approach for least tern chicks part way through the study. During 2009-12, one colored celluloid band was applied above the joint of each leg (tibia), a colored band below the joint of one leg (tarsometatarsus), and a USGS aluminum metal band below the joint of the other leg. Chicks were recaptured and weighed on subsequent visits. When they were approximately 15 days post-hatch, color bands were moved from the upper to the lower part of the leg to increase potential for resighting. This approach was necessary because very young least tern chicks cannot carry 2 bands on the same leg segment because of small leg size. It was determined that band loss issues with celluloid bands were substantial, so the banding approach was adjusted in 2013 by applying a unique two-character alpha-numeric Darvic plastic band and a USGS size 1A stainless steel metal band below the joint of opposite legs on each least tern chick. This banding approach appears to be superior because band retention is substantially higher for Darvic alpha-numeric bands than for celluloid bands on least terns. Nesting habitats were surveyed approximately 2-3 times a week to identify color-banded individuals that had reached fledging age (greater than or equal to 21 days old for plovers, greater than or equal to 16 days old for terns). Surveys consisted of stationing 1 or 2 technicians with spotting scopes offshore or around the perimeter of sandpits, conducting systematic searches of sandpits or riverine sites, and recapturing tern chicks when necessary to confirm identification. All field activities were conducted according to protocol outlined in Federal Threatened and Endangered permit no. TE121914-7.

\section{Data Analysis}

\section{Reproductive Success-Nest Survival Rates}

Because nest visits were frequent and most nests were found in laying stage, apparent nest success was deemed an appropriate, unbiased estimator of productivity (Johnson and Shaffer, 1990; Shaffer, 2004; Sherfy and others, 2012b). Daily nest survival rates were estimated separately for least terns 
and piping plovers. A nest was considered to have survived an interval between nest visits if at least one egg was present in the nest at the end of the interval or if it was concluded the nest hatched (Grant and others, 2005). There was no evidence for directional bias in the survival of nests of unknown fate and thus unknown-fate nests were excluded from all analyses. All models were built using package 'RMark' (Laake, 2013) in program $\mathrm{R}$ and all survival parameters were estimated using program MARK (White and Burnham, 1999).

Models were parameterized such that survival was dependent on the following covariates: age of the nest at initial discovery (NestAge), initiation date (InitiationDate), and year (Year). Because most of the existing sites in the analysis were not monitored (but probably existed and were used as nesting sites) before 2001, there was no attempt to associate an exact 'age' to these sites. Instead, in analyses where sites were divided into either 'first year available' or 'after first year available', all 'existing' sites were included in the 'after first year available' class (that is, covariate 'SiteAgeClass'). Whether nest survival rates for both species differed relative to the age class (SiteAgeClass) of the site on which they were initiated was examined. For example, in the year nesting habitat was first available at a site this site was considered part of the 'first year available' age class. Sites that had existed for more than one year were considered part of the 'after first year available' age class. Finally, we examined whether nests initiated on sites that had been created (Created), through either physical construction of a new site or new vegetation management regimes, during the 2009-14 interval differed from those that were preexisting. These 'created' sites included Leaman East (Sandpit), Broadfoot - Newark West, Cottonwood Ranch PRRIP Island, Cottonwood Ranch Sandpit, and Dyer Sandpit (see table 1). Because of a low number of samples, there was no examination of the differences in nest survival based on whether nests were initiated at sandpit or river locations.

Covariates were added in a stepwise fashion; the first model set included each covariate individually, which was then compared to a 'null' (intercept only) model. Models were ranked using Akaike's Information Criterion adjusted for small sample size (AICc); the model with the lowest AICc value was considered the most parsimonious. Covariates whose inclusion had resulted in a model that had outcompeted the null model or top model from the previous step were added to the top model from the previous step. Finally, additive associations between covariates were explored. The top models from each step in the model selection tables were reported.

An abbreviated analysis of created sites of known-age only was used to examine whether age class effects were due to whether a site was a created site or an 'existing' site (that is, a site with nesting habitat available before 2009) and whether there were any linear effects of actual site age (SiteAge). Sites of known age were collapsed into two classes: first year available for nesting and after first year available (for site-specific 'first year available' see table 1). By using sites of only known ages 'site age' (that is, the number of years that had passed since initial availability of a site) was able to be included as a continuous covariate in the analysis. The process of model selection described in the previous paragraph was followed.

\section{Reproductive Success-Chick Survival to Fledging Age}

Daily resightings and recaptures of uniquely marked piping plover and least tern chicks and Cormack-Jolly-Seber (CJS) models in program MARK (White and Burnham, 1999) were used to analyze age-structured capture histories and estimate the daily apparent survival $(\varphi)$ and detection probability $(p)$ of both species. Although piping plover chicks were considered fledged if alive at 21 days and least tern chicks were considered fledged at 16 days of age, capture histories were allowed to extend slightly past this point because sites were not always visited on the exact day of fledging. There were 25 occasion capture histories created for piping plovers banded at younger than 21 days of age and 18 occasion capture histories created for least terns banded at younger than 16 days of age. For each occasion (that is, day of age), a chick received a 1 if its site was visited and the chick was resighted or recaptured, a 0 if the site was visited but the chick was not seen, and was censored (.) if the site was not visited. Due to data limitations differences in chick survival based on whether chicks hatched at sandpit or river locations were not examined.

Models of all combinations of our parameterizations for detection and apparent survival probability were built using package RMark in program $\mathrm{R}$ and estimated parameters for apparent survival and detection using program MARK. The degree of overdispersion ( $\hat{c}$ ) was estimated using program RELEASE and then used to calculate quasi-AICc (QAICc), which was then used to rank models. The model with the lowest QAICc value was considered the most parsimonious.

For both species, models were parameterized such that detection probability was dependent on chick age as a log-linear trend (Age) and the year a chick was hatched and resighted (Year). The effect of targeted searching (Target), which designated days on which crews were only visiting sites to resight/recapture chicks, was controlled for. To account for the fact that detection probability was likely different on days in which targeted chick searches took place, the covariate 'Target' was added to our parameterization of chick detection (see Roche and others, 2014).

When parameterizing models for apparent survival, covariate effects were examined by modeling chick-age as a log-linear trend (Age) and adding the year a chick was hatched and resighted (Year). In addition, whether survival rates for both species differed relative to the age class (SiteAgeClass) of the site on which they were hatched was examined. For example, in the year nesting habitat was first available at a site, this site was considered part of the 'first year available' age class. Sites that had existed for more than 1 year were considered part of the 'after first year available' age class.

All parameterizations for detection probability were fit first. In all cases, the parameterization of apparent survival 
was constrained to a model in which survival was described as an additive effect of 'Age' and Year'. Parameterizations of detection probability were built that were described by (1) a null model, (2) Age, (3) Target, (4) Age + Target, (5) Target + Year, and (6) Age + Target + Year. The top model (lowest QAICc) was selected for our parameterization of detection probability when parameterizing and selecting among models for apparent survival.

When parameterizing models for apparent survival, covariates were added in a stepwise fashion; the first model set included each covariate individually, which was then compared to a null (intercept only) model. Models were ranked using QAICc; the model with the lowest QAICc value was considered the most parsimonious. All covariates whose inclusion had resulted in a model that had outcompeted the null model or top model from the previous step were included in the top model from the previous step. Finally, only additive associations between covariates and nest survival were explored. The top models from each step in the model selection tables were reported.

\section{Colonization}

There was a subset of 11 sites included in the colonization analysis (table 1). Of these 11 sites, 8 were sites that were considered created through either physical construction or habitat modification (for example, vegetation removal) and well-monitored by USGS crews during 2009-14 (hereafter referred to as 'created' sites). These created sites included the following: Binfield Islands, Broadfoot-Kearney South, Broadfoot-Newark West, Cottonwood Ranch PRRIP Island, Cottonwood Ranch Sandpit, Dyer Sandpit, Leaman East (Sandpit), and Leaman West (Islands). Three of these sites were located on the Platte River, whereas the other five were sandpit sites. For comparative purposes, three sandpit sites were included that existed before 2009 and were consistently monitored by USGS crews during 2009-14 (hereafter 'existing' sites). These existing sites included the following: Blue Hole, Johnson Sandpit, and Lexington Sandpit. At all sites and for both species, USGS crews monitored nests, banded chicks and adults, and resighted throughout the course of the season (2009-14).

For sites that were created during 2009-14 (and thus were of known age) site age (covariate 'SiteAge') was calculated as the current year, less the first year in which nesting habitat was available at a site, plus 1 year. For example, if habitat modification took place half-way through 2011, the site was not considered 'available' for nesting until 2012 (when the site had an age of 1 year); in 2013 this site would be considered 2 years old (for example, $2013-2012+1=2$ ). The year nesting habitat was considered to have first been available at a site is presented in table 1. Because most of the existing sites in the analysis were not monitored (but probably existed and used as nesting sites) before 2001, there was no attempt to associate an exact 'age' to these sites. Instead, in analyses where sites were divided into either 'first year available' or 'after first year available', all 'existing' sites were included in the 'after first year available' class (covariate 'SiteAgeClass'). When uniquely marked piping plovers and least terns were of known age (that is, banded as chicks) and nesting at one of the aforementioned 11 sites during 2010-14, they were assigned to one of two age classes: first year nesting adult (FY) or after first year nesting adult (AFY). As banding began in 2009, before 2010, there were no uniquely marked FY birds.

Information on band resighting collected during nest monitoring was used to summarize the number of unbanded piping plovers or least terns relative to the number of marked piping plovers or least terns for each site in each year (2009-14). Finally, as with previous summaries, the number of nests present at each site in each year was tabulated for both species. The summaries were restricted to piping plovers and least terns of known age (that is, banded as chicks).

General linear regression models were built to assess the effect of site age on the number of nests present at a site. In each analysis, the effect of the following covariates was investigated: 'SiteAge' (in years), 'SiteAgeClass' (that is, either 'first year available' or 'after first year available'), species (Species), as well as species by site age and site age class combinations. Models were compared relative to a null model with no covariates. Models were ranked using AICc and the results from the top-ranked model (that is, lowest AICc) were interpreted. Only sites and individual birds of known age were included in these analyses.

\section{Apparent Survival of Juveniles and Nesting Adults}

Annual resighting and recapture data collected on uniquely marked adult piping plovers and least terns observed in the Central Platte River Valley during 2009-14 and CJS models built-in program MARK were used to estimate the annual apparent survival and detection probability for both species. So that estimates of juvenile survival for piping plovers would be comparable with other published estimates, individuals banded as chicks were only included in the analysis if they were recaptured or resighted between 20-35 days of age (approximate fledging age, see Catlin and others, 2014). For least terns, individuals banded as chicks were included if they were recaptured or resighted between 16-30 days of age (approximate fledging age, Roche and others, 2014). Although this reduced the sample size, by following this process, prefledging mortality was excluded from the estimates of juvenile survival.

Cormack-Jolly-Seber models produce estimates of 'apparent survival', in which true survival is confounded with site fidelity, and 'detection probability', in which true detection (whether or not a bird that is present is seen) is confounded with temporary emigration from a resighting location. Because of consistent field effort and field methodologies during the 2009-14, it was assumed the annual probability of detecting a uniquely marked least tern or piping plover was 
constant. For piping plovers intercept-only parameterizations for $p$ were built; however, least terns are not believed to return to the breeding grounds until their second year as an adult (Massey and others, 1992). As a result, least tern detection was modeled with two age-classes and no year effects. Detection probability was fixed to 0 for least terns in their first year as an adult.

Models for apparent survival were parameterized based on age class only (AgeClass; that is, juvenile survival compared to adult survival). Year-specific apparent survival or detection probabilities were not estimated because of small sample sizes. CJS models were built using package RMark in program $\mathrm{R}$ and generated parameter estimates using program MARK. The degree of overdispersion ( $\hat{c})$ was estimated using the median-ĉ test and this was used to calculate quasiAICc (QAICc), which was then used to rank models. The model with the lowest QAICc value was considered the most parsimonious.

\section{Dispersal and Philopatry}

Recapture and resighting data were used to quantify the number of times uniquely identifiable individuals moved between nesting sites to describe how uniquely marked piping plovers and least terns were using habitat in the Central Platte River Valley. These data were summarized based on the number of uniquely marked individuals that moved between habitat types (river or sandpit) and by individual site as after first year adults (that is, movements between the first nesting attempt through multiple years) or as first year adults (that is, movement between hatch site habitat type and first nesting attempt habitat type).

Two forms of dispersal were computed for both species: natal dispersal - the distance between the first observed nest of an adult bird and the nest at which it hatched at, and nesting adult dispersal - the distance between the first nest of an adult in year ${ }_{t-1}$ and the first nest of that same adult in year . $^{\text {. }}$ When adults were not observed nesting in consecutive years, the nesting adult dispersal was calculated as the distance between the location of the first nest at the last recorded nesting event and the location of the first nest at the subsequent nesting event. For example, if an adult nested in 2012, was not observed nesting in 2013, but then was again observed nesting in 2014, adult dispersal distance was calculated as the distance between the first nest in 2012 and the first nest in 2014. We chose to include non-consecutive nesting years in our analyses because our sample sizes were small and thus we wished to include all available data so as to completely describe movement between nesting locations. Although, by this example, we would not know where the individual nested in 2013, by including all information, we would know if the individual used a different site in 2012 than in 2014 and how far away these locations were from each other. However, the 'dispersal distance', cannot be interpreted as if a plover or tern made a straight-line flight between the locations. The R package "sp" (Pebesma and Bivand, 2005; Bivand and others, 2013) was used to compute the straight-line distance between the Universal Transverse Mercator (UTM) nest locations of nests.

\section{Renesting}

Because within-year inter-nest dispersal, otherwise known as renesting, was of special interest, each of these events was examined separately from the summary of interannual dispersal. Package "sp" in program R was used to compute the straight-line distance between the UTM locations of nests initiated in the same year by the same uniquely marked individual. Each association of an adult with a nest within a year was considered a unique inter-nest dispersal movement. Each unique inter-nest dispersal movement was classified according to (1) whether the adult moved to a new site or stayed on the same site, (2) the adult moved to a different habitat type (that is, river or sandpit), (3) the adult moved to a 'created' or 'existing' site, (4) the fate of the first nest, and (5) the fate of renest.

For uniquely marked least terns and piping plovers that renested, the mean initiation dates of first nests and renests were calculated for all years (2009-14). Additionally, the average interval between the estimated termination date of the first nest and the initiation date of the second (or subsequent) nest was calculated and this value was used to calculate mean renesting intervals for the study period. For each year, the number of first nests initiated by at least one uniquely marked adult and the number of known 'renests' initiated by at least one uniquely marked adult were reported. The total number of uniquely identifiable least terns and piping plovers known to have nested and known to have renested was also reported. No information on nests associated with non-uniquely marked adults were included as these could not be accurately classify as 'first nests' or 'renests'.

\section{Migratory, Winter, and other non-Central Platte River Valley Resightings of Piping Plovers}

All resightings of piping plovers banded in the Central Platte River Valley and observed elsewhere were compiled and summarized by state and year of the observation. A unique event was defined as a banded bird within a season (that is, we counted 2 unique events if the same bird was seen in 2 different years on the wintering grounds, and 1 unique event if the same bird was seen multiple times in the same season). Only individuals with complete color band combinations that could be associated with a USGS metal band number as a unique identity were included. 


\section{Results}

\section{Reproductive Success-Nest Survival Rates}

Least Terns.-A total of 366 least tern nests monitored at river ( $n=4$ nests) and sandpit ( $n=362$ nests) focal sites during 2009-14 were included in the nest survival analysis (table 2). Of the 362 least tern nests, 29 (8 percent of those monitored) were initiated in the first year a site was available for nesting. During 2009-14, mean daily nest survival was 0.9742 (95-percent CI: 0.9692-0.9783) and, using daily survival estimates from the intercept-only (constant survival) model, cumulative survival of least tern nests was 0.59 (95-percent CI: 0.53-0.65) from the date the first egg was laid through the end of incubation (21 days). Models that incorporated annual variation in daily nest survival rates were supported for least terns (table 3 ) suggesting that nest survival rates were annually variable (see fig. 2). Additionally, as the age of the tern nest at its discovery increased, survival decreased ( $\hat{\beta}_{\text {nestage }}=-0.07,95$-percent CI: -0.11 to -0.02$)$ and daily nest survival rates were higher at older sites (those in the 'after first year available' site age class; see fig. 3). For the 181 least tern nests included in the abbreviated analysis of nest survival relative to site age and site age class at sites created since 2009, year continued to explain more of the variability in nest survival than the age class of the site a least tern nest was initiated on (table 4).

Piping Plovers.-A total of 148 piping plover nests monitored at river ( $n=10$ nests) and sandpit ( $n=138$ nests) focal sites during 2009-14 were included in the nest survival analysis (table 5). Of these, 7 piping plover nests (5 percent of those monitored) were initiated in the first year a site was available for nesting. During 2009-14, mean daily nest survival was 0.9880 (95-percent CI: 0.9836-0.9912) and, using daily survival estimates from the intercept-only (constant survival) model, cumulative nest survival was 0.66 (95-percent CI: 0.57-0.74) from the date the first egg was laid through the end of incubation (35 days) (fig. 4). Models that incorporated annual variation in daily nest survival rates received little support for piping plovers (table 6). For the 59 piping plover nests included in the abbreviated analysis of nest survival relative to site age and site age class only at sites created since 2009, there was no evidence that site age or age class played a role in explaining variability in nest survival for piping plovers (table 7).

\section{Reproductive Success-Chick Survival to Fledging Age}

Least Terns.-Chick survival was estimated for 523 least tern chicks hatched from river ( $n=2$ chicks) or sandpit ( $n=$ 521 chicks) focal sites during 2009-14 (for total marked during 2009-14 see table 8). Of the 523 least tern chicks, 32 (6 percent of those marked) were hatched on a site in the first year it was available. The best-supported model for least tern chick survival included chick age, year, and age class of the hatch site all as additive (that is, non-interacting) effects (table 9). Mean daily chick survival was 0.9602 (95-percent CI: 0.9515-0.9673) and cumulative chick survival to fledging (16 days) using daily survival estimates from the interceptonly model was 0.54 (95 -percent $\mathrm{CI}=0.48-0.61$; see fig. 5). The probability of a chick surviving to fledging, however, was approximately 1.5 times higher at older sites (that is, those in the 'after first year available' site age class) than in the first year of nesting habitat availability (see fig. 6).

Piping Plovers.-Chick survival was estimated for 408 piping plover chicks hatched from river ( $n=17$ chicks) or sandpit ( $n=391$ ) focal sites during 2009-14 (for total marked during 2009-14 see table 8). Of the 408 piping plover chicks, only 18 ( 5 percent of those marked) were hatched on a site in the first year it was available. The best-supported model for piping plover chick survival was an intercept-only model (table 10) suggesting chick survival to fledging (21 days) did not differ significantly by year, chick age, or site age class. Mean daily chick survival was 0.9621 (95-percent CI: 0.9514-0.9706) and cumulative chick survival to fledging using daily survival estimates from the intercept-only model was 0.46 (95-percent $\mathrm{CI}=0.37-0.56$; see fig. 7).

\section{Colonization}

Least Terns.-A total of 33 nests were documented at created sites during the first year of the site's availability: there were 3 nests found at Broadfoot-Kearney South in 2010, 19 nests found at Broadfoot-Newark West in 2011, 5 nests found at Dyer Sandpit in 2011, and 6 nests found at Leaman East (sandpit) in 2013. The number of least tern nests present at a created site was associated with the age class of that site (see table 11), with more tern nests associated with older sites (that is, those in the 'after first year available' site age class).

There were no uniquely marked least terns that either nested or were observed at a created site in the first year it was available. There were 3 least terns that were observed on created sites as AFY individuals; 2 least terns had originally hatched at Blue Hole, and 1 least tern had originally hatched at Broadfoot-Kearney South. No banded least terns were seen on a site in the first year it was available (see table 12). 
Table 2. Number of successful and failed least tern nests on the Central Platte River Valley during 2009-14 included in the nest survival analysis.

[Unknown-fate nests were excluded from nest survival analysis.]

\begin{tabular}{lccccccc}
\hline & $\mathbf{2 0 0 9}$ & $\mathbf{2 0 1 0}$ & $\mathbf{2 0 1 1}$ & $\mathbf{2 0 1 2}$ & $\mathbf{2 0 1 3}$ & $\mathbf{2 0 1 4}$ & Total \\
\hline Success & 22 & 27 & 33 & 46 & 31 & 64 & 223 \\
Fail & 9 & 17 & 23 & 13 & 26 & 55 & 143 \\
Total & $\mathbf{3 1}$ & $\mathbf{4 4}$ & $\mathbf{5 6}$ & $\mathbf{5 9}$ & $\mathbf{5 7}$ & $\mathbf{1 1 9}$ & $\mathbf{3 6 6}$ \\
\hline
\end{tabular}

Table 3. Nest survival models used to estimate daily nest survival rates for least tern nests initiated in the Central Platte River Valley during 2009-14.

[Models were ranked using Akaike's Information Criterion adjusted for small sample size (AICc); here we present the change in AICc relative to the top model $(\triangle \mathrm{AICc})$, the number of model parameters $(\mathrm{k})$, and the model deviance (Deviance). (' $S$ ': daily nest survival, ' + ': designates an additive relationship, 'Intercept': intercept model, 'Created': a site was either 'created' or 'pre-existing' [categorical], 'NestAge': the age in days of the nest when first found [continuous], 'InitiationDate': the ordinal date the nest was initiated [continuous], 'Year': the year [categorical] the nest was initiated, 'SiteAgeClass': as site was either in the 'first year of availability' or in a year 'after the first year of availability' [categorical]).]

\begin{tabular}{lccc}
\hline \multicolumn{1}{c}{ Model $(\boldsymbol{S})$} & k & $\Delta$ AICc & Deviance \\
\hline Year + NestAge + SiteAgeClass* & 8 & 0.00 & 834.61 \\
Year + NestAge & 7 & 2.03 & 838.64 \\
Year & 6 & 6.17 & 844.79 \\
Intercept & 1 & 17.15 & 865.78 \\
\hline
\end{tabular}

*AIC for the top-ranked model was 850.6 .

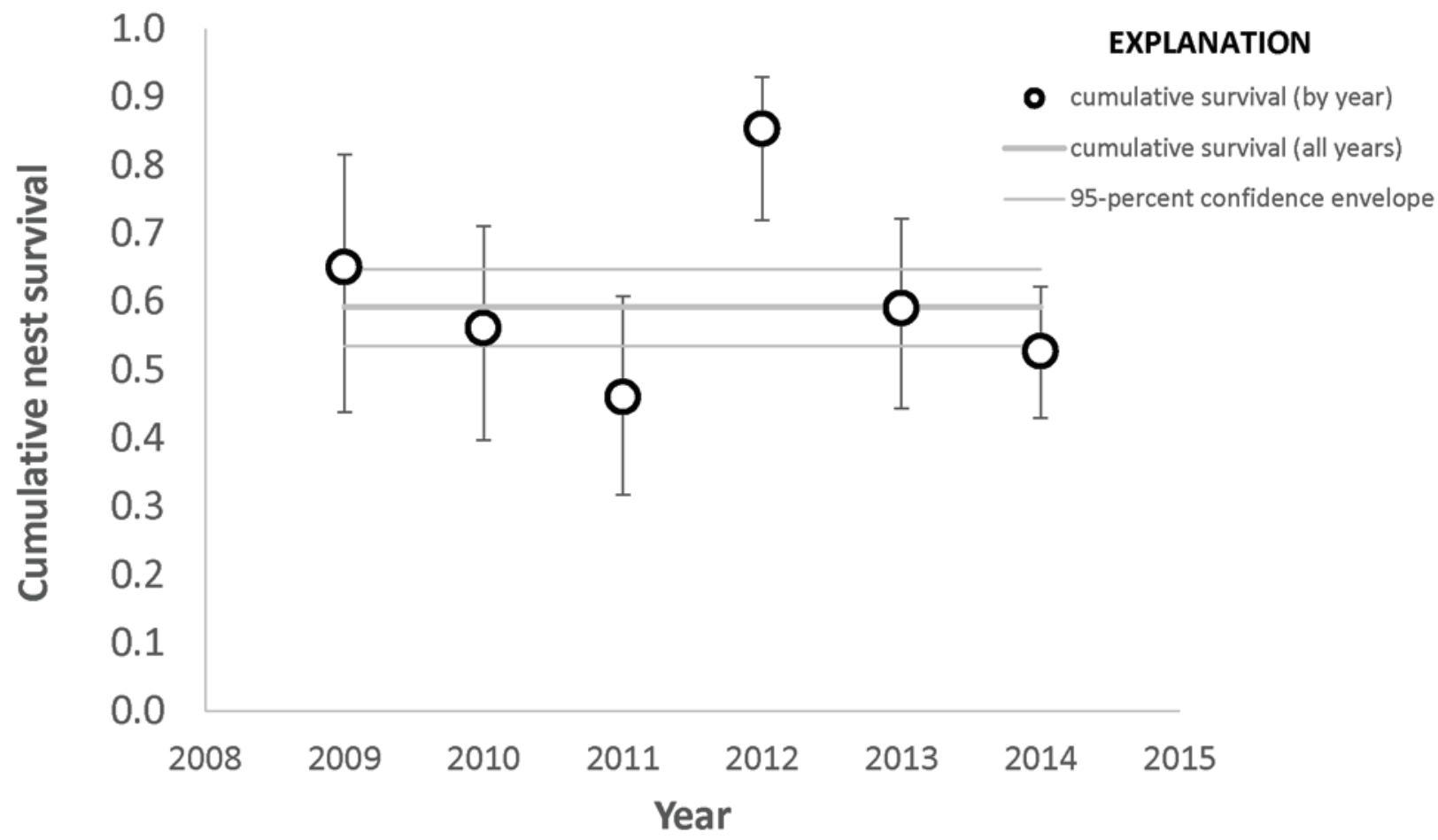

Figure 2. Cumulative nest survival (21 days) rates of least tern nests in the Central Platte River Valley, 2009-14. (Circles with vertical bars represent annual cumulative survival estimates with 95-percent confidence intervals generated from model $S[$ Year + NestAge; table 3]. The thick horizontal gray line with two additional thin gray lines represents the mean cumulative survival estimate and 95-percent confidence intervals respectively during 2009-14 generated from model $S$ [Intercept; table 3]). 


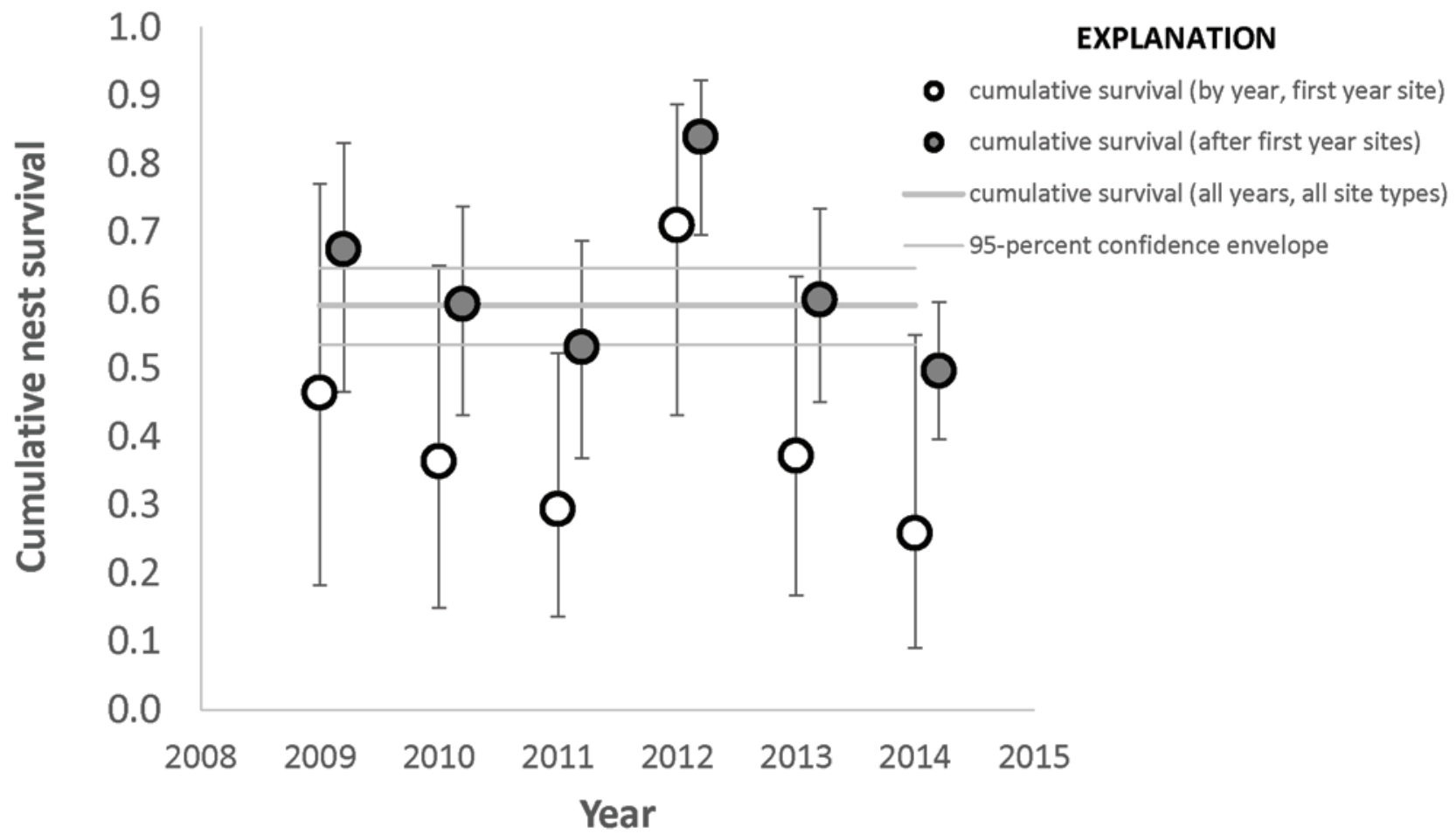

Figure 3. Cumulative nest survival rates (21 days) based on nest site age class for least tern nests initiated in the Central Platte River Valley, 2009-14. (Open circles indicate the first year of site availability. Closed circles indicate a year after the first year of site availability. Circles with vertical bars represent annual cumulative survival estimates with 95-percent confidence intervals generated from $S[$ Year + NestAge + SiteAgeClass; table 3]. The thick horizontal gray line with two additional thin gray lines represents the mean cumulative survival estimate and 95-percent confidence intervals respectively during 2009-14 generated from model $S$ [Intercept; table 3].)

Table 4. Nest survival models used to estimate daily nest survival rates for least tern nests initiated on created sites in the Central Platte River Valley during 2009-14.

[Models were ranked using Akaike's Information Criterion adjusted for small sample size (AICc); here we present the change in AICc relative to the top model $(\triangle \mathrm{AICc})$, the number of model parameters $(\mathrm{k})$, and the model deviance (Deviance). (' $S$ ': daily nest survival, '+': designates an additive relationship, 'Intercept': intercept model, 'Created': a site was either 'created' or 'pre-existing' [categorical], 'NestAge': the age in days of the nest when first found [continuous], 'InitiationDate': the ordinal date the nest was initiated [continuous], 'Year': the year [categorical] the nest was initiated, 'SiteAgeClass': as site was either in the 'first year of availability' or in a year 'after the first year of availability' '+': designates an additive relationship [categorical], 'SiteAge': the number of years a site has been available to be nested at [continuous]).]

\begin{tabular}{llcc}
\hline \multicolumn{1}{c}{ Model $(\boldsymbol{S})$} & k & $\Delta$ AICc & Deviance \\
\hline Year* & 5 & 0.00 & 373.02 \\
SiteAgeClass + Year & 6 & 0.39 & 371.40 \\
SiteAgeClass & 2 & 1.94 & 380.98 \\
Intercept & 1 & 10.22 & 391.26 \\
SiteAge & 1 & 75.07 & 456.11 \\
\hline
\end{tabular}

*AIC for the top-ranked model was 383.0. 
Table 5. Number of successful and failed piping plover nests in the Central Platte River Valley during 2009-14 included in the nest survival analysis.

[Unknown-fate nests were excluded from nest survival analysis.]

\begin{tabular}{lccccccc}
\hline & $\mathbf{2 0 0 9}$ & $\mathbf{2 0 1 0}$ & $\mathbf{2 0 1 1}$ & $\mathbf{2 0 1 2}$ & $\mathbf{2 0 1 3}$ & $\mathbf{2 0 1 4}$ & Total \\
\hline Success & 3 & 12 & 20 & 23 & 18 & 32 & 108 \\
Fail & 5 & 9 & 6 & 8 & 5 & 7 & 40 \\
Total & $\mathbf{8}$ & $\mathbf{2 1}$ & $\mathbf{2 6}$ & $\mathbf{3 1}$ & $\mathbf{2 3}$ & $\mathbf{3 9}$ & $\mathbf{1 4 8}$ \\
\hline
\end{tabular}

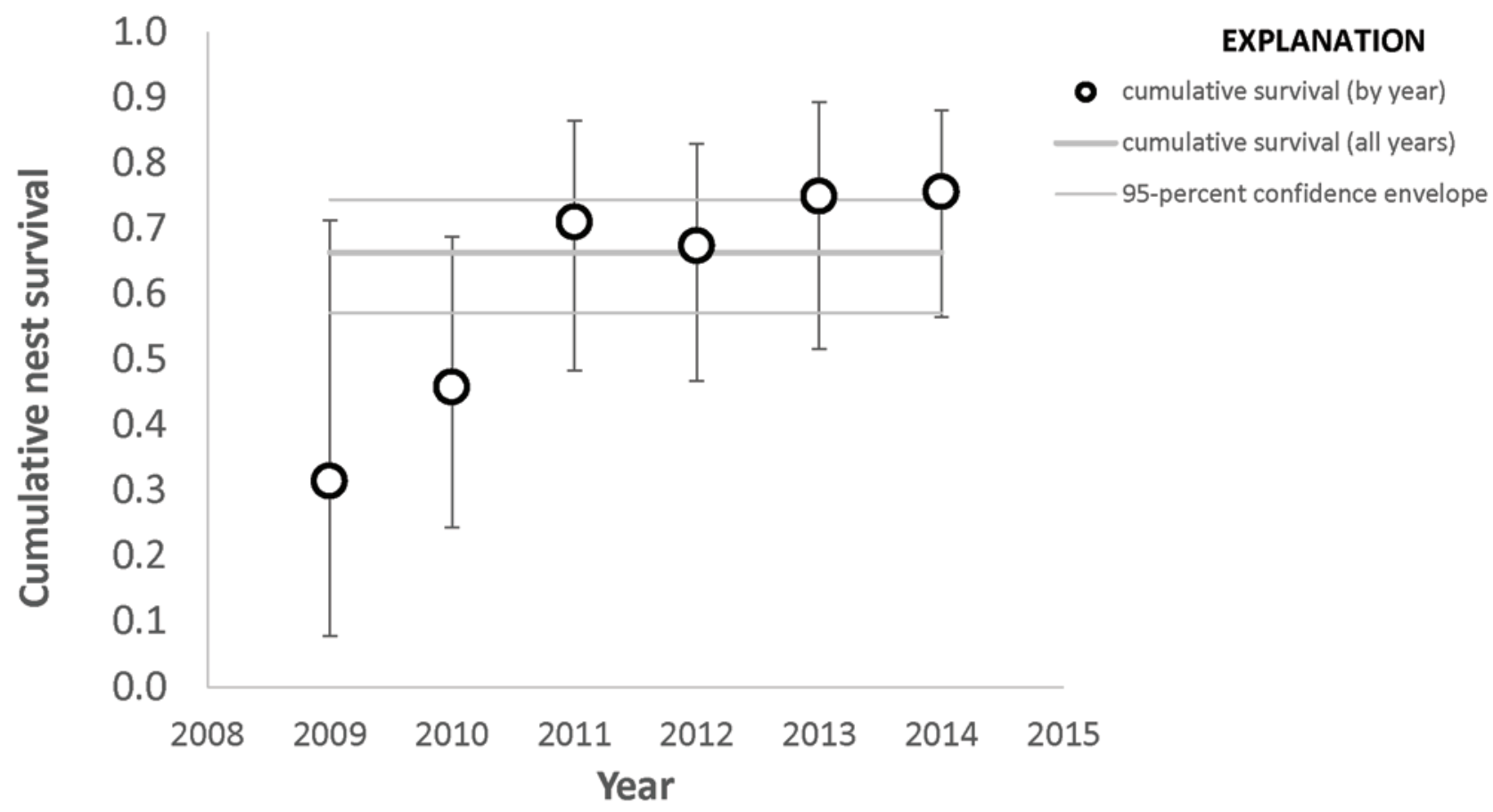

Figure 4. Cumulative nest survival rates of piping plover nests (35 days) in the Central Platte River Valley, 2009-14. (Circles with vertical bars represent annual cumulative survival estimates with 95-percent confidence intervals generated from $S[$ Year; table 6]. The thick horizontal gray line with two additional thin gray lines represents the mean cumulative survival estimate and 95-percent confidence intervals respectively for 2009-14 generated from model $S$ [Intercept; table 6].) 
Table 6. Nest survival models used to estimate daily nest survival rates for piping plover nests initiated in the Central Platte River Valley during 2009-14.

[Models were ranked using Akaike's Information Criterion adjusted for small sample size (AICc); here we present the change in AICc relative to the top model $(\triangle \mathrm{AICc})$, the number of model parameters $(\mathrm{k})$, and the model deviance (Deviance). (' $S$ ': daily nest survival, '+': designates an additive relationship, 'Intercept': intercept model, 'Created': a site was either 'created' or 'pre-existing' [categorical], 'NestAge': the age in days of the nest when first found [continuous], 'InitiationDate': the ordinal date the nest was initiated [continuous], 'Year': the year [categorical] the nest was initiated, 'SiteAgeClass': a site was either in the 'first year of availability' or in a year 'after the first year of availability' [categorical]).]

\begin{tabular}{llcc}
\hline \multicolumn{1}{c}{ Model $(\boldsymbol{S})$} & k & $\Delta$ AICc & Deviance \\
\hline Intercept* & 1 & 0.00 & 344.63 \\
NestAge & 2 & 0.07 & 342.70 \\
InitiationDate & 2 & 0.94 & 343.57 \\
Created & 2 & 1.05 & 343.69 \\
SiteAgeClass & 2 & 1.40 & 344.03 \\
Year & 6 & 1.76 & 336.37 \\
\hline
\end{tabular}

*AIC for the top-ranked model was 346.64 .

Table 7. Nest survival models used to estimate daily nest survival rates or piping plover nests initiated on sites created in the Central Platte River Valley during 2009-14.

[Models were ranked using Akaike's Information Criterion adjusted for small sample size (AICc); here we present the change in AICc relative to the top model $(\triangle \mathrm{AICc})$, the number of model parameters $(\mathrm{k})$, and the model deviance (Deviance). (' $S$ ': daily nest survival, '+': designates an additive relationship, 'Intercept': intercept model, 'Created': a site was either 'created' or 'pre-existing' [categorical], 'NestAge': the age in days of the nest when first found [continuous], 'InitiationDate': the ordinal date the nest was initiated [continuous], 'Year': the year [categorical] the nest was initiated, 'SiteAgeClass': a site was either in the 'first year of availability' or in a year 'after the first year of availability' [categorical], 'SiteAge': the number of years a site has been available to be nested at [continuous]).]

\begin{tabular}{llcc}
\hline \multicolumn{1}{c}{ Model $(\boldsymbol{S})$} & k & $\Delta$ AICc & Deviance \\
\hline Intercept* & 1 & 0.00 & 128.12 \\
NestAge & 2 & 1.51 & 127.63 \\
SiteAgeClass & 2 & 1.70 & 127.81 \\
InitiationDate & 2 & 1.99 & 128.10 \\
Year & 4 & 3.98 & 126.07 \\
SiteAge & 2 & 66.26 & 194.38 \\
\hline
\end{tabular}

*AIC for the top-ranked model was 130.12 .

Table 8. Number of least terns and piping plovers banded by age and year in the Central Platte River Valley (2009-14).

\begin{tabular}{llccrrrrr}
\hline \multicolumn{1}{c}{ Species } & Age & $\mathbf{2 0 0 9}$ & $\mathbf{2 0 1 0}$ & $\mathbf{2 0 1 1}$ & $\mathbf{2 0 1 2}$ & $\mathbf{2 0 1 3}$ & $\mathbf{2 0 1 4}$ & Total \\
\hline Least tern & Adult & 16 & 7 & 4 & 9 & 33 & 28 & 97 \\
Least tern & Chick & 35 & 74 & 98 & 103 & 99 & 114 \\
Piping plover & Adult & 9 & 12 & 2 & 12 & 12 & 11 \\
Piping plover & Chick & 25 & 64 & 68 & 86 & 64 & 106 \\
\hline
\end{tabular}


Table 9. Cormack-Jolly-Seber survival models used to estimate daily survival rates for least tern chicks hatched in the Central Platte River Valley during 2009-14.

[Models were ranked using Quasi-Akaike's Information Criterion adjusted for overdispersion ( $\hat{c}=0.71)$ and small sample size (QAICc); here we present the change in QAICc relative to the top model ( $\triangle$ QAICc), the number of model parameters (k), and the model deviance (QDeviance). (' $\varphi$ ': daily survival rates, '+': designates an additive relationship, 'Intercept': intercept model, 'Age': a log-linear trend of chick age in days [continuous], 'Year': the year [categorical] the nest was initiated, 'SiteAgeClass': a site was either in the 'first year of availability' or in a year 'after the first year of availability' [categorical], 'Target': age-specific covariate indicating that the site a chick was hatched on was the subject of a 'targeted' search [time-varying, categorical]). For all models detection probability $(p)$ was parameterized as $p($ Target + Age + year $)$.

\begin{tabular}{lrcc}
\hline \multicolumn{1}{c}{ Model $(\boldsymbol{\varphi})$} & k & $\Delta$ OAICc & QDeviance \\
\hline Age + Year + SiteAgeClass* & 15 & 0.00 & $4,230.61$ \\
Age + Year & 14 & 0.78 & $4,233.45$ \\
Intercept & 9 & 40.21 & $4,283.07$ \\
\hline
\end{tabular}

*QAIC for the top-ranked model was 4,261.01.

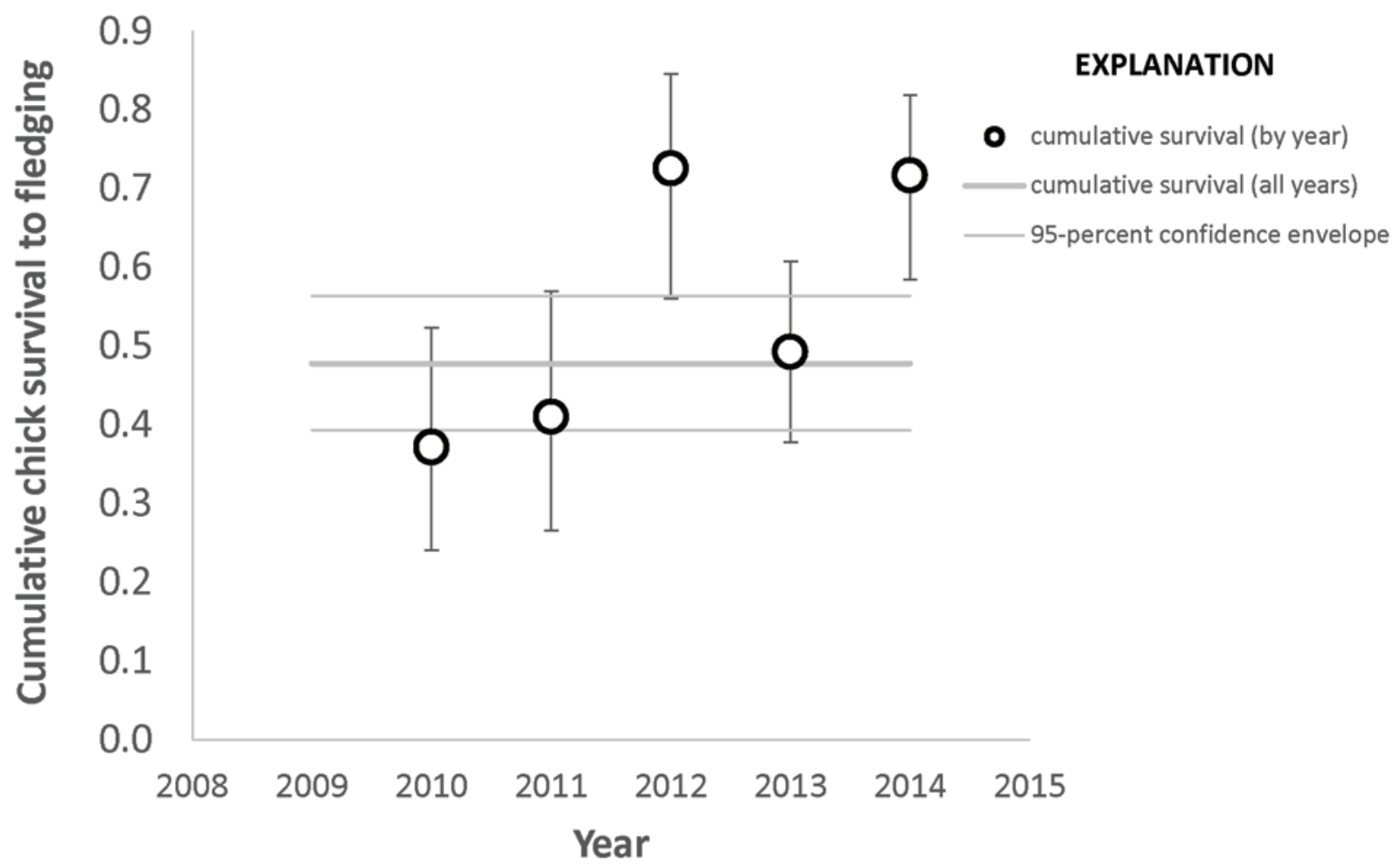

Figure 5. Cumulative survival rates of least tern chicks to fledging age (16 days) in the Central Platte River Valley, 2009-14. (Circles with vertical bars represent annual cumulative survival estimates with 95-percent confidence intervals generated from model $\varphi[$ Age + Year; table 9.]. The thick horizontal gray line with two additional thin gray lines represents the mean cumulative survival estimate and 95-percent confidence intervals respectively during 2009-14 generated from model $\varphi$ [Intercept; table 9].) 


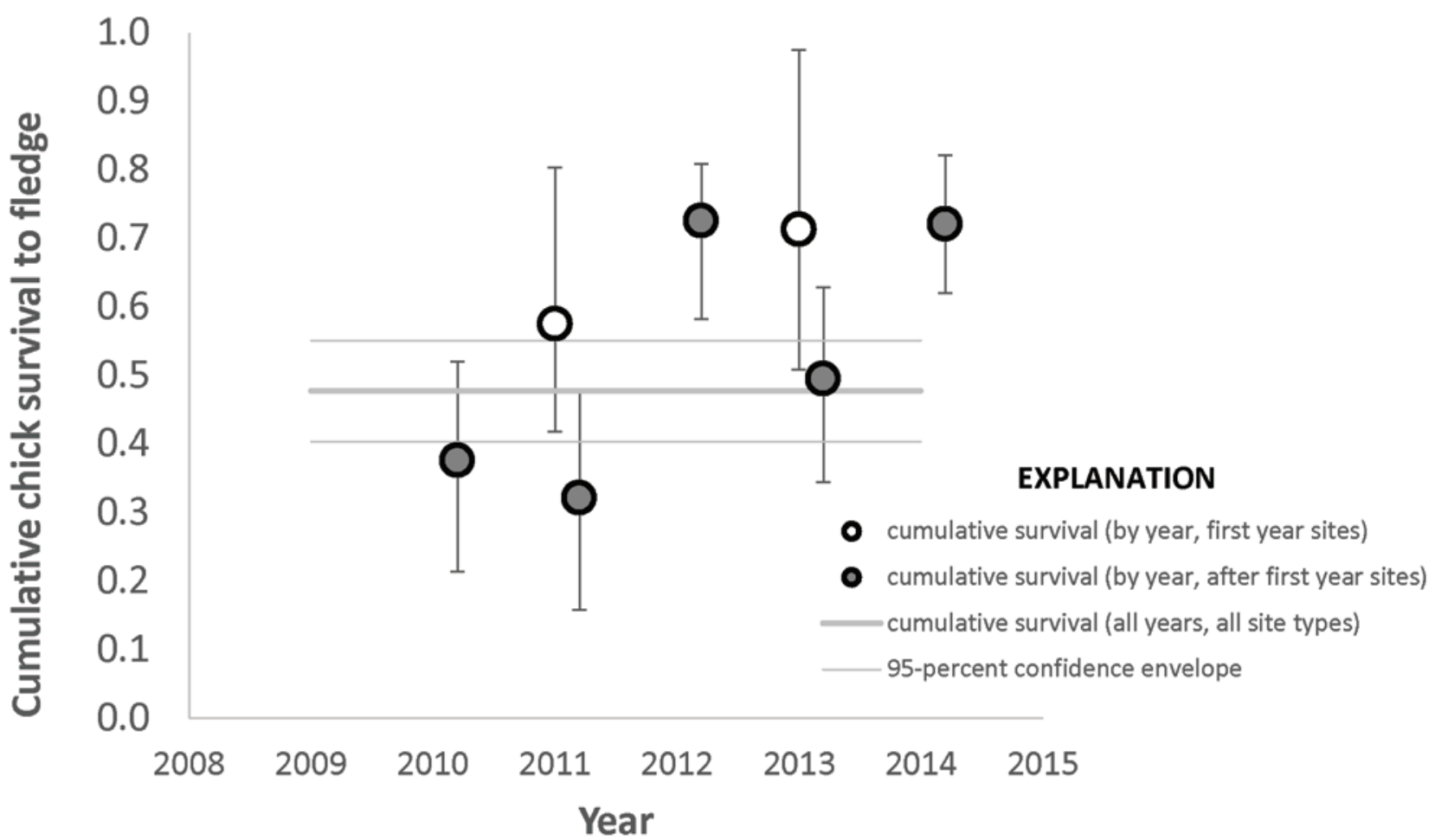

Figure 6. Cumulative survival rates of least tern chicks to fledging age (16 days) based on site age class at which chicks were hatched in the Central Platte River Valley, 2009-14. (Open circles indicate the first year of site availability. Closed circles indicate a year after the first year of site availability. Circles with vertical bars represent annual cumulative survival estimates with 95-percent confidence intervals generated from model $\varphi[$ Age + Year + SiteAgeClass; table 9]. The thick horizontal gray line with two additional thin gray lines represents the mean cumulative survival estimate and 95-percent confidence intervals respectively during 2009-14 generated from model $\varphi[$ Intercept; table 9].)

Table 10. Cormack-Jolly-Seber survival models used to estimate daily apparent survival rates for piping plover chicks hatched in the Central Platte River Valley during 2009-14.

[Models were ranked using Quasi-Akaike's Information Criterion adjusted for overdispersion $(\hat{\mathrm{c}}=2.19)$ and small sample size (QAICc); here we present the change in QAICc relative to the top model ( $\triangle$ QAICc), the number of model parameters (k), and the model deviance (QDeviance). (' $\varphi$ ': daily apparent survival, '+': designates an additive relationship, 'Intercept': intercept model, 'Year': the year [categorical] the nest was initiated, 'Age': a log-linear trend of chick age in days [continuous], 'Target': age-specific covariate indicating that the site a chick was hatched on was the subject of a 'targeted' search [time-varying, categorical]). For all models detection probability $(p)$ was parameterized $p$ (Target + Age + year $).]$

\begin{tabular}{lccc}
\hline \multicolumn{1}{c}{ Model $(\varphi)$} & $\mathbf{k}$ & $\Delta$ OAICc & QDeviance \\
\hline Intercept* & 9 & 0.00 & $1,496.82$ \\
Age & 10 & 0.93 & $1,495.72$ \\
Year & 13 & 6.71 & $1,495.40$ \\
\hline
\end{tabular}

*QAIC for the top-ranked model was 1,514.94. 


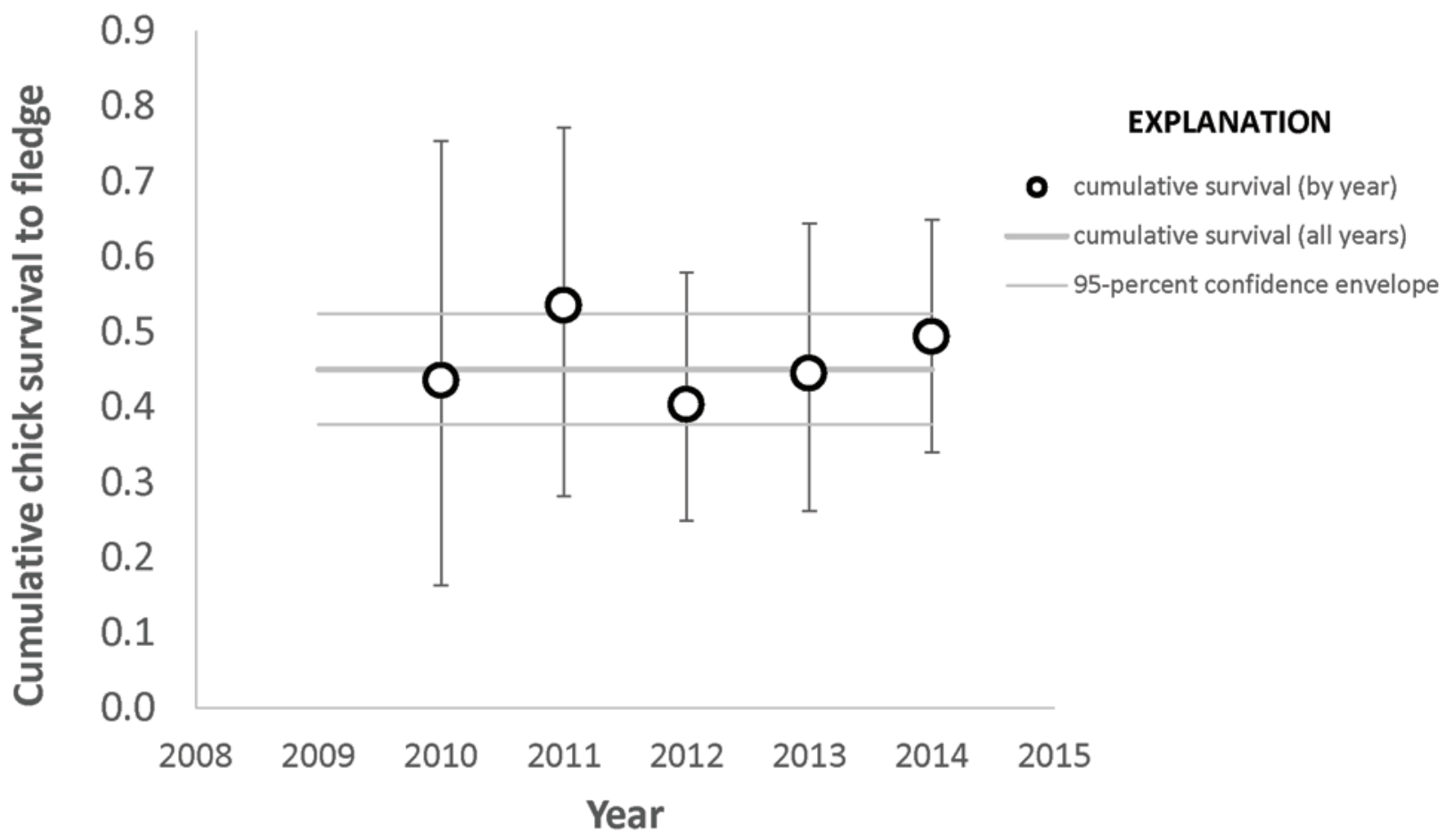

Figure 7. Cumulative survival rates of piping plover chicks to fledging age (21 days) in the Central Platte River Valley, $2009-14$. (Circles with vertical bars represent annual cumulative survival estimates with 95-percent confidence intervals generated from model $\varphi[$ Year; table 10]. The thick horizontal gray line with two additional thin gray lines represents the mean cumulative survival estimate and 95-percent confidence intervals respectively for 2009-14 generated from model $\varphi[$ [Intercept; table 10].]

Table 11. Summary of least tern nests found at sites created in the Central Platte River Valley during 2009-14 by site age in years (first year through fifth year) and site age class (first year available and after first year available) used in linear and logistic regression analyses.

['Site Age': the number of years a site has been available for nesting, 'Site Age Class': a site was either in the 'first year of availability' or in a year 'after the first year of availability', ' $n$ ': total number of nests.]

\begin{tabular}{lc}
\hline \multicolumn{1}{c}{ Category } & $\boldsymbol{n}$ \\
\hline Site age - & \\
First year & 33 \\
Second year & 68 \\
Third year & 48 \\
Fourth year & 42 \\
Fifth year & 11 \\
Site age class - & \\
First year available & 33 \\
After first year available & 169 \\
\hline
\end{tabular}


Table 12. Summary of uniquely marked least terns resighted or recaptured on sites created in the Central Platte River Valley during 2009-14 by site age in years, site age class, and tern age class used in linear and logistic regression analyses.

['FY': first year nesting adult, 'AFY': after first year, 'Site Age': the number of years a site has been available for nesting, 'Site Age Class': a site was either in the 'first year of availability' or in a year 'after the first year of availability', Age Class: age class of resighted/recaptured terns, ' $n$ ': total number of uniquely identifiable least terns.]

\begin{tabular}{ccc}
\hline \multicolumn{1}{c}{ Category } & Age class & $\boldsymbol{n}$ \\
\hline Site age - & & \\
First year & FY & 0 \\
& AFY & 0 \\
Second year & FY & 0 \\
& AFY & 1 \\
Third year & FY & 0 \\
& AFY & 0 \\
Fourth year & FY & 0 \\
Fifth year & AFY & 1 \\
& FY & 0 \\
Site age class - & AFY & 1 \\
First year available & FY & 0 \\
After first year available & AFY & 0 \\
& FY & 0 \\
& AFY & 3 \\
\hline
\end{tabular}

Piping Plovers.-Although, in general, created sites did not have nests in their first year, a total of 7 nests initiated in the first year of a site were documented: 2 nests at Broadfoot-Kearney South in 2010, 2 nests at Cottonwood Ranch PRRIP Island in 2014, 2 nests at Dyer Sandpit in 2011, and 1 nest at Leaman East (sandpit) in 2013. The number of piping plover nests present at a created site also was associated with the age class of that site (see table 13), with more piping plover nests associated with older sites (that is, those in the 'after first year available' site age class). However, in general, there were fewer piping plover nests found at created sites than least tern nests. The presence of least tern and piping plover nests at created sites was similarly associated with the site age class $\left(\hat{\beta}_{\text {SiteAgeClass(afterfirstyear) }}=2.12\right)$ with nests of both species approximately 1.7 times more likely to be present at older sites relative to sites in their first year of availability $\left(\hat{\beta}_{\text {Intercept }}=0.0\right.$; as calculated by log odds).

There were two uniquely marked piping plovers that nested at a created site in the first year it was available: one at Cottonwood Ranch PRIPP Island in 2014 and the other at Dyer Sandpit in 2011. In both cases, the piping plovers were first-year nesting adults and had hatched at Blue Hole. There were 23 uniquely marked piping plovers of known age recaptured or resighted on created sites as first-year individuals.
Table 13. Summary of piping plover nests found at sites created in the Central Platte River Valley during 2009-14 by site age in years and site age class used in linear and logistic regression analyses.

['Site Age': the number of years a site has been available for nesting, 'Site Age Class': a site was either in the 'first year of availability' or in a year 'after the first year of availability', ' $n$ ': total number of nests.]

\begin{tabular}{lc}
\hline \multicolumn{1}{c}{ Category } & $\boldsymbol{n}$ \\
\hline Site age - & 7 \\
First year & 21 \\
Second year & 13 \\
Third year & 17 \\
Fourth year & 9 \\
Fifth year & \\
Site age class - & 7 \\
First year available & 60 \\
After first year available & \\
\hline
\end{tabular}

Of these, 12 hatched at Blue Hole, 3 hatched at Lexington Sandpit, 5 hatched at Trust Wildrose-East, 1 hatched at Leaman East, 1 hatched at Broadfoot-Newark West, and 1 hatched at Elm Creek Island Complex West. In addition, 9 of the 23 FY piping plovers were observed on a created site during the first year the site was available. There were 17 piping plovers observed on created sites as individuals in a year after their first year (AFY) ( 7 of these were seen in previous years on created sites as FY individuals). Of the 9 piping plovers that were observed on created sites for the first time as AFY individuals, 1 hatched at Trust Wildrose-East, 1 at Broadfoot-Kearney South, 1 hatched at Blue Hole, 1 hatched at Dippel Tract, 1 hatched at Dyer Sandpit, 2 hatched at Johnson Sandpit, and 2 hatched at Lexington Sandpit. There were no AFY piping plovers observed on sites in the first year of their availability (table 14). Additionally, sites that had been available for nesting longer, had a higher number of AFY piping plovers observed at them relative to FY plovers (table 14).

\section{Apparent Survival of Juveniles and Nesting Adults}

Least Terns.—Juvenile (that is, age of first banding as a chick to first year as an adult) and adult annual apparent survival was estimated for 262 uniquely identifiable least terns that were first marked as either a chick or an adult. The annual apparent survival estimate for adult least terns was 0.42 (95-percent $\mathrm{CI}=0.22-0.64)$ and was 0.14 (95-percent $\mathrm{CI}=$ $0.04-0.41$ ) for juvenile least terns. The annual detection probability for least terns was 0.42 (95-percent $\mathrm{CI}=0.17-0.71$ ).

Piping Plovers.- Juvenile (that is, age of first banding as a chick to first year as an adult) and adult annual apparent survival was estimated for 247 uniquely identifiable piping 
Table 14. Summary of uniquely marked piping plovers resighted or recaptured at sites created in the Central Platte River Valley during 2009-14 by site age in years, site age class, and plover age class used in linear and logistic regression analyses.

['FY': first year nesting adult, 'AFY': after first year, 'Site Age': the number of years a site has been available for nesting, 'Site Age Class': a site was either in the 'first year of availability' or in a year 'after the first year of availability', 'Age Class': age class of resighted/recaptured terns, ' $n$ ': total number of uniquely identifiable piping plovers).]

\begin{tabular}{ccc}
\hline \multicolumn{1}{c}{ Category } & Age class & $\boldsymbol{n}$ \\
\hline Site age - & & \\
First year & FY & 9 \\
& AFY & 0 \\
Second year & FY & 7 \\
& AFY & 5 \\
Third year & FY & 2 \\
Fourth year & AFY & 13 \\
Fifth year & FY & 5 \\
& AFY & 9 \\
Site age class - & FY & 2 \\
First year available & AFY & 4 \\
After first year available & FY & \\
& FFY & 9 \\
\hline
\end{tabular}

plovers that were first marked as either a chick or an adult. The annual apparent survival estimate for adult piping plovers was 0.76 (95-percent $\mathrm{CI}=0.65-0.85$ ) and was 0.20 (95-percent $\mathrm{CI}=0.14-0.29)$ for juvenile piping plovers. The annual detection probability piping plovers was $0.69(95$-percent $\mathrm{CI}=$ $0.56-0.79)$.

\section{Dispersal and Philopatry}

Least Terns.-Four least tern chicks hatched from the Central Platte River Valley and were subsequently captured on nests as adults, providing insight into age at first breeding and hatch-year dispersal tendencies (table 15). Of these, three nested as adults in the second year after hatch, and one was not caught until 4 years after hatch. Two least terns returned to nest on the same site at which they had hatched (one at Broadfoot-Kearney South and one at Blue Hole) for a mean distance of $0.153 \mathrm{~km} \pm 0.069$ kilometers $(\mathrm{km})$ standard deviation (SD). The remaining 2 birds moved to new nesting areas; one moved from Blue Hole to Cottonwood Ranch Sandpit (a distance of $10 \mathrm{~km}$ ), and one emigrated from Broadfoot-Newark West to the Garrison Reach (not shown) of the Missouri River (a distance of $749 \mathrm{~km}$ ) for a mean distance of $380 \mathrm{~km} \pm 523 \mathrm{~km}$
Table 15. Central Platte River Valley hatch sites and sites where a first nesting attempt was observed for four uniquely identifiable least terns marked and resighted/recapture during 2009-14.

[ $n$, total number of individuals]

\begin{tabular}{lll}
\hline \multicolumn{1}{c}{ Hatch site } & \multicolumn{1}{c}{ First nesting site } & $\boldsymbol{n}$ \\
\hline Blue Hole & Blue Hole & 1 \\
Blue Hole & Cottonwood Ranch Sandpit & 1 \\
Broadfoot-Kearney South & Broadfoot-Kearney South & 1 \\
Broadfoot-Newark West & $\begin{array}{l}\text { Garrison Reach, } \\
\text { Missouri River }\end{array}$ & 1 \\
& & Total: \\
\end{tabular}

(SD). With the exception of the least tern who immigrated to the Missouri River, all other hatch year dispersal events were to sandpit habitat. Additionally, there were two least terns whose first nesting attempt was made at a site that was created during 2009-14 (Broadfoot-Kearney South, Cottonwood Ranch Sandpit).

There were nine adult least terns that nested in more than 1 year, allowing us to investigate adult dispersal and philopatry (table 16). There were 10 instances in which an adult least tern could either switch to nest at a new location or remain at the previous location with the onset of a new year. In five (50 percent) of these instances, least terns returned to nest on the site where they had nested in a previous year. In the five instances terns remained at the same nesting site between years, the mean distance between the nest sites was $0.069 \mathrm{~km}$ $\pm 0.023 \mathrm{~km}$ (SD). In the five instances least terns switched nesting sites between years, the mean distance between nest sites was $30 \mathrm{~km} \pm 25 \mathrm{~km}$ (SD). In all cases, least terns switched between sandpit habitat nesting sites. There were two least terns that switched from nesting at a preexisting nest site to a nest site that was created during 2009-14 (Blue Hole to Leaman East [Sandpit] and Lexington Sandpit to Cottonwood Ranch Sandpit).

Piping Plovers.-There were 12 piping plover chicks that hatched from the Central Platte River Valley and were subsequently documented on nests as adults (table 17). Three of the 12 piping plover chicks were either captured or observed nesting the first year after hatch, 7 the second year after hatch, and 2 the third year after hatch. All piping plovers returned to nest on different sites from the one on which they hatched. The mean distance between hatch location and a first documented nesting location was $29 \mathrm{~km} \pm 16 \mathrm{~km}$ (SD). First nest attempts by after hatch-year dispersing birds were documented on seven different sites. With the exception of a single individual that dispersed from a hatch site on sandpit habitat (Blue Hole) to a first nesting site on the river (Cottonwood Ranch PRRIP Island), all individuals dispersed from hatch sites on sandpit habitat to nesting sites on sandpit habitat. Additionally, there were 7 piping plovers whose first nesting attempt was made at a site that was created during 2009-14: 3 nested at Broadfoot-Kearney South, 2 nested at Dyer Sandpit, 1 nested 
Table 16. Dispersal of uniquely marked least terns in the Central Platte River Valley during 2009-14.

$\left[n_{e}\right.$, total number of events; $n_{i}$, total number of individuals $]$

\begin{tabular}{llcc}
\hline Nest site (dispersed from) & Nest site (dispersed to) & $\boldsymbol{n}_{\boldsymbol{e}}$ & $\boldsymbol{n}_{\boldsymbol{i}}$ \\
\hline Blue Hole & Blue Hole & 2 & 2 \\
Blue Hole & Leaman East (Sandpit) & 1 & 1 \\
Broadfoot-Kearney South & Broadfoot-Kearney South & 2 & 2 \\
Broadfoot-Kearney South & Broadfoot-Newark West & 1 & 1 \\
Broadfoot-Kearney South & Leaman East (Sandpit) & 1 & 1 \\
Dyer Sandpit & Cottonwood Ranch Sandpit & 1 & 1 \\
Dyer Sandpit & Dyer Sandpitritrandit & 1 & 1 \\
Lexington Sandpit & Cottonwood Ranch Sandpit & 1 & 1 \\
& $\quad$ Total: & $\mathbf{1 0}$ & $\mathbf{1 0}$ \\
\hline
\end{tabular}

Table 17. Central Platte River Valley hatch sites and sites where a first nesting attempt was observed for uniquely identifiable piping plovers marked and resighted/recapture during 2009-14.

[n, total number of individuals $]$

\begin{tabular}{lll}
\hline \multicolumn{1}{c}{ Hatch site } & \multicolumn{1}{c}{ First nesting site } & n \\
\hline Blue Hole & Broadfoot-Kearney South & 1 \\
Blue Hole & Cottonwood Ranch PRRIP Island & 1 \\
Blue Hole & Dyer Sandpit & 2 \\
Blue Hole & Lexington Sandpit & 1 \\
Broadfoot-Newark West & Paulsen's Lexington Pit & 1 \\
Johnson Sandpit & Broadfoot-Kearney South & 1 \\
Lexington Sandpit & Blue Hole & 3 \\
Lexington Sandpit & Broadfoot-Kearney South & 1 \\
Lexington Sandpit & Cottonwood Ranch Sandpit & 1 \\
& & $\mathbf{1 2}$ \\
\hline
\end{tabular}

at Cottonwood Ranch Sandpit, and 1 nested at Cottonwood Ranch PRRIP Island.

There were 36 adult piping plovers that nested in more than 1 year (table 18). There were 45 instances in which an adult plover could either switch to nest at a new location or remain at the previous location with the onset of a new year. In 39 of these cases ( 87 percent), the adult nested on the same site as its prior documented nesting attempt and in 6 of these instances the adult switched to a new nesting location between years. Mean distance moved between nest sites for the 39 cases was $0.085 \mathrm{~km} \pm 0.097 \mathrm{~km}(\mathrm{SD})$. In the six instances in which the adult nested on a different site from its prior documented nesting attempt, the distance moved between nest sites for these birds was $21 \mathrm{~km} \pm 15 \mathrm{~km}$ (SD). In all cases, piping plovers switched between sandpit habitat nesting sites. There were two plovers that switched from nesting at a preexisting nest site to a site that was created during 2009-14 (Blue Hole to Broadfoot-Newark West, Johnson Sandpit to Broadfoot-Newark West).

\section{Renesting}

Least Terns.-There were no renests observed among the 84 nests initiated by uniquely marked least terns during 2009-14 and no renests documented among the 83 uniquely marked least terns observed nesting during the same study period (table 19).

Piping Plovers.- Out of the 111 nests initiated by at least 1 uniquely marked piping plover, there were 15 renests documented (14 percent; table 20). Of these 15 renests, 7 (47 percent) were initiated following the termination of a nest that was either 'successful' (that is, hatched at least 1 chick) or 'probably successful', 6 (40 percent) were initiated following the failure of a nest, and 2 were initiated following the termination of a nest of unknown fate. There were 13 (87 percent) renests fated as either successful or probably successful, 1 renest that failed, and 1 renest with an unknown fate. 
Table 18. Dispersal of uniquely marked piping plovers in the Central Platte River Valley during 2009-14.

$\left[n_{e}\right.$, total number of events; $n_{i}$, total number of individuals $]$

\begin{tabular}{llcc}
\hline Nest site (dispersed from) & Nest site (dispersed to) & $\boldsymbol{n}_{\boldsymbol{e}}$ & $\boldsymbol{n}_{\boldsymbol{i}}$ \\
\hline Blue Hole & Blue Hole & 11 & 8 \\
Blue Hole & Broadfoot-Newark West & 1 & 1 \\
Blue Hole & Johnson Sandpit & 1 & 1 \\
Broadfoot-Kearney South & Broadfoot-Kearney South & 6 & 5 \\
Broadfoot-Newark West & Broadfoot-Newark West & 2 & 2 \\
Cottonwood Ranch Sandpit & Broadfoot-Kearney South & 1 & 1 \\
Cottonwood Ranch Sandpit & Cottonwood Ranch Sandpit & 1 & 1 \\
Dyer Sandpit & Dyer Sandpit & 10 & 7 \\
Dyer Sandpit & Johnson Sandpit & 1 & 1 \\
Johnson Sandpit & Blue Hole & 1 & 1 \\
Johnson Sandpit & Broadfoot-Newark West & 1 & 1 \\
Johnson Sandpit & Johnson Sandpit & 1 & 1 \\
Lexington Sandpit & Lexington Sandpit & 8 & 6 \\
& & $\mathbf{4 5}$ & $\mathbf{3 6}$ \\
\hline
\end{tabular}

Table 19. Number of successful, failed, and unknown fate nests and renests attended by at least one uniquely identifiable least tern in the Central Platte River Valley during 2009-14.

[Renests are denoted with parentheses]

\begin{tabular}{lccccccc}
\hline & $\mathbf{2 0 0 9}$ & $\mathbf{2 0 1 0}$ & $\mathbf{2 0 1 1}$ & $\mathbf{2 0 1 2}$ & $\mathbf{2 0 1 3}$ & $\mathbf{2 0 1 4}$ & Total \\
\hline Success & 0 & 6 & 2 & 8 & 17 & 58 & 25 \\
Fail & 0 & 1 & 0 & 1 & 0 & 9 & 18 \\
Unknown & 2 & 0 & 1 & $\mathbf{3}$ & $\mathbf{9}$ & $\mathbf{2 7}$ & $\mathbf{8 4}$ \\
Total & $\mathbf{2}$ & $\mathbf{7}$ & & & & $\mathbf{3 6}$ \\
\hline
\end{tabular}

Of the 75 uniquely marked piping plovers that were observed nesting during this period, there were 13 individuals documented renesting at least once (17 percent). Of the 13 birds that renested, 5 (38 percent) of them initiated renests on nesting habitat that was created during 2009-14, whereas 8 (62 percent) of them initiated renests at existing nesting habitat (that is, nesting habitat that existed before 2009; see table 1). All first nests and renests were initiated on sandpit nesting habitat. In all but one case, piping plovers renested at the same site as the first nest initiated that season. The bird that moved between sites initiated its first nest at Blue Hole and its second nest at Broadfoot-Newark West, a straight-line distance of approximately $36 \mathrm{~km}$. This renesting event also represents a within-season movement to a 'younger' nesting location. The mean distance, however, that the bird moved between first and second nests was $0.073 \mathrm{~km} \pm 0.06$ (SD) for birds that stayed on the same site. For birds that renested, the mean initiation date of the first nest was May 6 and the mean initiation date of the second nest was June 8. On average, renests were initiated 7.5 days \pm 7.3 (SD) following the date the initial nesting attempt was 'fated' (that is, considered either failed or hatched).

\section{Migratory, Winter, and other non-Central Platte River Valley Resightings of Piping Plovers}

There were 34 uniquely identifiable piping plovers and no uniquely identifiable least terns reported at sites that were not part of the Central Platte River Valley during the breeding season. Wintering grounds sightings accounted for 21 of the reports, with 16 reports coming from the Texas Coast (not shown) and 5 coming from Florida (not shown) (4 from the Gulf Coast and 1 from the Atlantic Coast; fig. 8). These reports included 11 from within critical habitat units (4 in Florida, 7 in Texas). 
Table 20. Number of successful, failed, and unknown fate nests and renests attended by at least one uniquely identifiable piping plover in the Central Platte River Valley during 2009-14.

[Renests are denoted with parentheses]

\begin{tabular}{lcccccrr}
\hline & $\mathbf{2 0 0 9}$ & $\mathbf{2 0 1 0}$ & $\mathbf{2 0 1 1}$ & $\mathbf{2 0 1 2}$ & $\mathbf{2 0 1 3}$ & $\mathbf{2 0 1 4}$ & \multicolumn{1}{c}{ Total } \\
\hline Success & 4 & 8 & $5(2)$ & $10(4)$ & $15(2)$ & $27(5)$ & $111(13)$ \\
Fail & 1 & 0 & 1 & 5 & 4 & $2(1)$ & $40(1)$ \\
Unknown & 5 & 3 & 1 & $7(1)$ & 2 & 0 & $25(1)$ \\
Total & $\mathbf{1 0}$ & $\mathbf{1 1}$ & $\mathbf{7 ( 2 )}$ & $\mathbf{2 2 ( 5 )}$ & $\mathbf{2 1 ( 2 )}$ & $\mathbf{4 1 ( 6 )}$ & $\mathbf{1 7 6 ( 1 5 )}$ \\
\hline
\end{tabular}

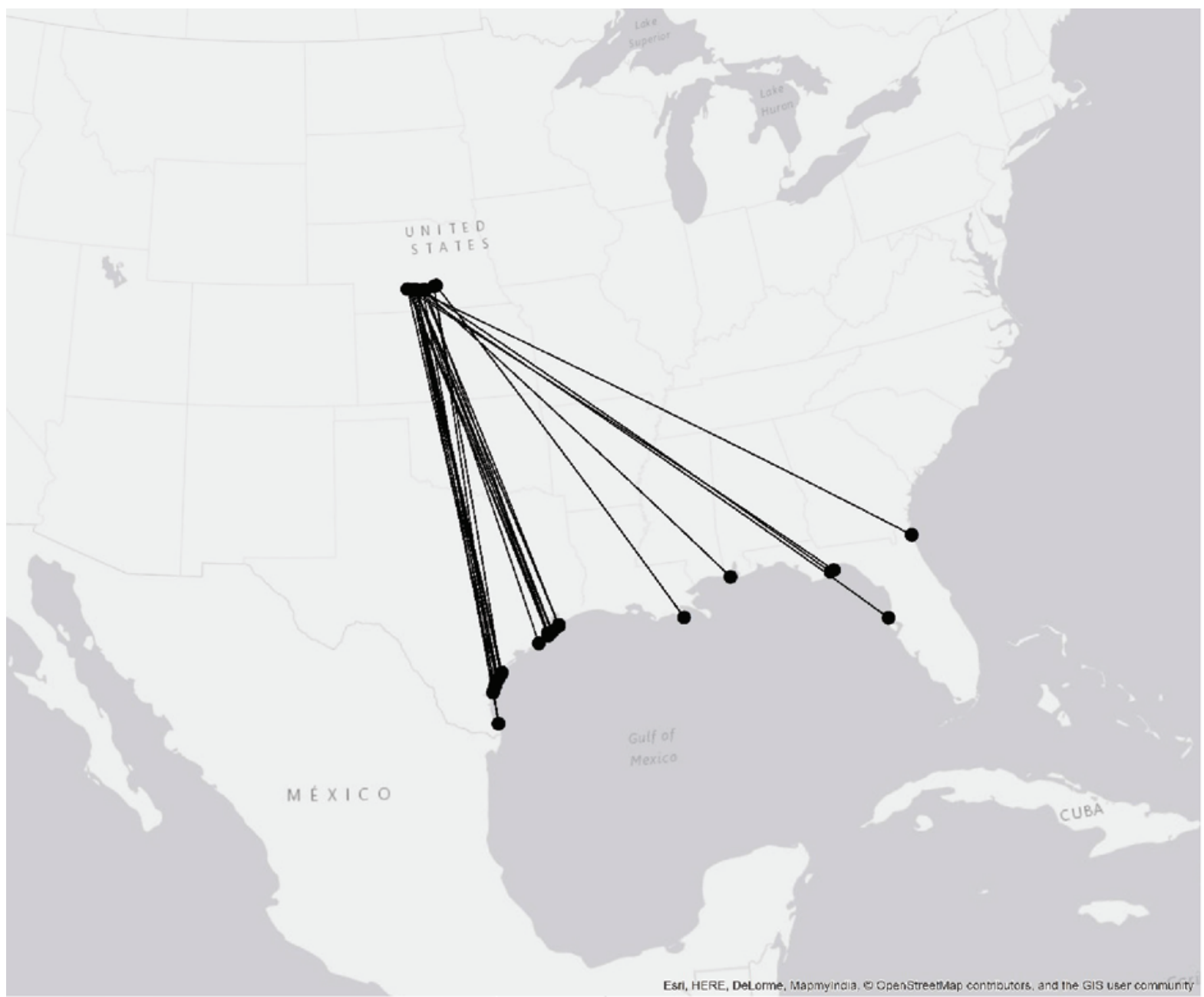

Figure 8. Wintering ground observations of piping plovers uniquely marked in the Central Platte River Valley, $2009-14$.

There were 13 reports of birds banded in the Central Platte River Valley from 7 other known nesting areas (table 21). These included five sites in Nebraska and two out-of-state sites: John Martin Reservoir in Colorado (not shown) and the Lewis and Clark Lake in South Dakota (not shown). There were 19 piping plovers observed in the Central Platte River Valley that were originally banded in other locations. Thirteen piping plovers were originally banded on other breeding areas ( 7 on the Lower Platte River and 6 on the Missouri River in South Dakota). The remaining six birds were originally banded on the wintering grounds so their breeding ground affiliation is unknown. Two of the six birds were originally banded in Alabama (not shown) and four were originally banded in Texas (not shown). 
Table 21. Breeding locations for uniquely identifiable adult piping plovers originally banded in the Central Platte River Valley.

$[--$, no data $]$

\begin{tabular}{|c|c|c|c|c|c|c|}
\hline State & Location & 2010 & 2012 & 2013 & 2014 & Total \\
\hline Colorado & John Martin Reservoir & -- & -- & -- & 1 & 1 \\
\hline South Dakota & Lewis and Clark Lake & -- & 3 & -- & -- & 3 \\
\hline Nebraska & Lake McConaughy & -- & -- & -- & 3 & 3 \\
\hline Nebraska & Loup River & 1 & -- & -- & 1 & 2 \\
\hline Nebraska & Lower Platte River & -- & -- & -- & 1 & 1 \\
\hline Nebraska & North Platte & -- & -- & -- & 1 & 1 \\
\hline \multirow[t]{2}{*}{ Nebraska } & Niobrara River & -- & -- & 2 & -- & 2 \\
\hline & Total: & 1 & 3 & 2 & 7 & 13 \\
\hline
\end{tabular}

\section{Discussion}

Demographic data collected through mark-recapture and nest monitoring during 2009-14 allowed the estimation of vital rates for Central Platte River Valley breeding least terns and piping plovers in relation to environmental factors and place them in the context of the larger Great Plains (not shown).

\section{Reproductive Success}

Estimates of daily nest survival rates for both species were similar to estimates reported for off-river estimates reported for the Lower Platte River population of nesting least terns and piping plovers. During 2009-14, the geometric mean estimate for the daily survival probability of off-river least tern nests was 0.967 for the Lower Platte River population (Brown and others, 2009, 2010, 2011, 2012, 2013, 2014). Daily survival rates of 0.974 were estimated for least terns nesting in similar habitat type during 2009-14. The cumulative survival probability of survival from nest initiation to hatch for least tern nests initiated in the Central Platte River Valley (0.59) was lower than that of nests initiated on engineered sandbars (0.70) on the Gavin's Point Reach but higher than that of tern nests initiated on natural sandbars (0.37) along the same reach (Stucker and others, 2013; Shaffer and others, 2013). During 2009-14, the geometric mean estimate for the daily survival probability of off-river piping plover nests was 0.982 for the Lower Platte River population (Brown and others, 2009, 2010, 2011, 2012, 2013, 2014). Daily survival rates of 0.988 were estimated for piping plovers nesting in similar habitat type during 2009-14. These daily nest survival estimates were similar to those reported by Catlin and others, (2011) for piping plover nests on engineered sandbars (0.99 95-percent CI: $0.88-1.00)$ and on natural sandbars (0.98 95-percent CI: 0.80-1.00) occurring along the Gavin's Points Reach of the Missouri River during 2005-07.

Daily survival of least tern chicks hatched in the Central Platte River Valley (0.960) during 2009-14 was higher than those reported for chicks hatched on off-channel habitat in the Lower Platte River during 2009-14 (0.844) (Brown and others, 2009, 2010, 2011, 2012, 2013, 2014). The estimates of daily chick survival rates for least terns in the Central Platte River Valley were well within published estimates of daily chick survival for least terns hatched on the lower Mississippi River in Missouri (Dugger and others, 2000) and alkaline habitat in northwestern Oklahoma (Schweitzer and Leslie, 2000). Daily survival of piping plover chicks hatched in the Central Platte River Valley (0.961) during 2009-14 were slightly higher (although within the 95- percent CI) than those reported for chicks hatched on off-channel habitat in the Lower Platte River (0.932) during 2009-14 (Brown and others, 2009, 2010, 2011, 2012, 2013, 2014). Estimates of daily plover chick survival in the Central Platte River Valley were lower than those estimated for plover chicks hatched on Lewis and Clark Lake (Missouri River) during 2010 (0.984 \pm 0.006 SE; Hunt and others, 2013) but fell within the range of age-specific daily survival values $(0.86-0.98)$ reported for chicks hatched on the Gavin's Point Reach of the Missouri River during 2006-9 (Catlin and others, 2013).

Year and age-dependent variation in daily survival rates for least tern nests and chicks were estimable from data collected during 2009-14, but not for piping plovers. It is possible that there were annual or age-specific differences in piping plover survival rates, but that sample size restricted the ability to detect this variation. Least tern nest and chick survival was correlated with the age of the site class they were associated with, with nest survival at older sites associated with higher nest survival and lower chick survival. There was no relationship between site age class and plover chick and nest survival, but this was most likely due to the low sample size $\left(n_{\text {tern-nests }}=\right.$ 181 compared to $n_{\text {plover-nest }}=59$ ). Results for the Central Platte River Valley were different than what was described for piping plover nesting on engineered sandbars on the Missouri River, where nest success, although higher on engineered sandbars than natural sandbars, appeared to decrease with age of the sandbar (Catlin and others, 2011). 


\section{Colonization}

Least terns initiated more nests than piping plovers at sites with newly available nesting habitat. However, for both species, the number of nests found at a created site increased with the age of the site (that is, the number of years in which nesting habitat was available). A similar pattern was observed for piping plover nests initiated on newly engineered sandbars on the Gavin's Point Reach of the Missouri River during 2005-7 (Catlin and others, 2011). There were not any uniquely marked least terns that nested on newly created nesting habitat in the first year it was available, and only two that were ever detected nesting on newly created habitat. Both of the marked plovers of known age that nested at a site in the first year of its availability were first year breeders, as were all the marked individuals of known age that were resighted. Catlin (2009) documented first year nesting piping plovers were more likely to colonize natural sandbars along the Missouri River with low nesting densities rather than newly engineered sandbars with higher nesting densities despite the preference of after-firstyear nesters for engineered sandbars. In line with this observation, the proportion of first year nesters was determined to decrease the longer the created nesting habitat was available. Similar to Catlin (2009), we interpret this as suggesting inexperienced piping plovers are better able to colonize newly available habitat because of lack of competition. From a management standpoint, these observations suggest that hatch-year colonization of new breeding habitat is potentially an important demographic process for piping plovers and that years following high fledgling production may have good potential for establishing breeding pairs on new sites.

\section{Apparent Survival of Juveniles and Adults}

There are few published estimates of the annual apparent survival probability for adult least terns; however, estimates of annual adult apparent survival probability (0.42) in the Central Platte River Valley are lower than those reported for interior least terns nesting in the lower Mississippi River valley ( 0.85 95-percent CI: 0.73-0.95; Renken and Smith, 1995b) and California least terns (Sternula antillarum browni) nesting on Venice Beach, California (0.81 95-percent CI: 0.72-0.87; Massey and others, 1992). There are even fewer estimates available for the survival of juvenile least terns in their hatch year owing primarily to the low natal site fidelity; Massey and others, (1992) reported an annual apparent survival for juvenile California least terns of 0.16 (95-percent CI: 0.13-0.18). The estimate of 0.14 (95-percent CI: 0.04-0.41) reported here was similar to this estimate and consistent with known juvenile least tern behavior. Apparent survival estimates, although corrected for imperfect detection, are confounded by survival and site fidelity. It is more than likely that apparent survival estimates associated with Central Platte River Valley least terns are lower than other reported estimates because least terns are moving outside of the study area (that is, to unmonitored nesting habitat) between years. The fact that one of the four least terns marked as chicks and observed in a year following their hatch, emigrated out of the Central Platte River Valley to nest along the Missouri River in North Dakota, demonstrates such movement is possible (note: this least tern movement was excluded when estimating Central Platte River Valley apparent survival).

The estimate of annual apparent survival for adult piping plovers nesting in the Central Platte River Valley (0.76) was in line with other published estimates for adult piping plovers in the Great Plains $(0.72 \pm 0.04$ SE, Brown and others, 2014; 0.73 95-percent CI: $0.64-0.79$, Catlin and others, 2014). The estimates of annual apparent survival for juvenile piping plovers in the Central Platte River Valley $(0.20)$ was lower than that reported by Catlin and others, (2014) for the Gavin's Point Reach of the Missouri River (0.33 95-percent CI: 0.27-0.39) and by Brown and others, (2014) for the Lower Platte River $(0.47 \pm 0.13)$. All estimates for juvenile piping plover survival, however, were fairly imprecise (that is, wide confidence intervals associated with estimates) making it difficult to determine if there were real differences. Juvenile piping plovers disperse farther distances between years than do previously nesting adults (Amirault-Langlais and others, 2014), thus they have a higher probability of moving outside of a study area. Because mortality and permanent emigration are confounded in estimates of apparent survival, if juveniles are moving out of a study area and not resighted, this will appear as a lower estimate of apparent survival. The Tern and Plover Partnership (Lincoln, Nebr.), which is responsible for monitoring areas along the Lower Platte River, monitors an area larger than the Central Platte River Valley, is more likely to observe juvenile piping plovers that disperse far distances, and thus this region is less likely to suffer permanent emigration of juveniles (LeDee and others, 2010).

\section{Dispersal and Philopatry}

Natal dispersal and philopatry patterns were different between least terns and piping plovers. Only four least terns that were hatched and banded in the Central Platte River Valley were observed nesting as adults. Despite such a small number, there was a great degree of variability in the behavior of these four individuals. Two of these birds returned to their natal site for their first documented nesting attempt, a third moved to a different site that was still within the Central Platte River Valley, whereas the fourth left the Central Platte River Valley to breed along the Missouri River in North Dakota. There is little known about least tern natal fidelity other than it is low, which our handful of observations seems to support (Renken and Smith, 1995a). None of 12 piping plovers that returned to breed in a year following their hatch were observed nesting at their natal site, and only three were actually observed nesting as first year individuals. Piping plovers not only disperse farther as juveniles (Amirault-Langlais and others, 2014), but juveniles also do not necessarily breed 
in their first year even if they return to a breeding location (Saunders and others, 2014). Although dispersal distances for juvenile piping plovers were highly variable, the mean dispersal distance $(29 \mathrm{~km})$ was similar to published estimates from Atlantic Canada (28 km, Amirault-Langlais and others, 2014) and higher than the estimate from Manitoba/Minnesota (8-12 km; Haig and Oring, 1988), which in both cases also were highly variable.

Between-year dispersal distances for the nine adult least terns for which we had multiple years of nesting data also were highly variable ( $30 \mathrm{~km} \pm 25 \mathrm{~km}$, for five occasions in which least terns moved nesting sites). These results are in line with previously reported patterns for the dispersal of least terns; in a study of lower Mississippi River nesting least terns, Renken and Smith (1995a) reported that 97 percent of adult least terns returned to a site within $9 \mathrm{~km}$ of the site they were originally banded at as a nesting adult. Adult piping plovers appear to have a flexible dispersal strategy; in cases where habitat is stable or reproductive success is high they demonstrate site fidelity and low dispersal distances (Rioux and others, 2011; Amirault-Langlais and others, 2014). Where nesting habitat is dynamic or when reproductive success is low, however, piping plovers are more likely to disperse to new nesting areas (Rioux and others, 2011; Roche and others, 2012; Roche and others, 2014). During 2009-14, Central Platte River Valley nesting adult plovers exhibited relatively high site fidelity ( 87 percent) for the species, which is in line with what would be expected for a system that is either stable or saturated. Since there appears to be nesting habitat available in the Central Platte River Valley that goes unused by piping plovers, it is more likely that the high nest fidelity exhibited by Central Platte River Valley nesting plovers is due to the relative stability of the system and past reproductive success.

\section{Renesting}

There was no renesting documented among uniquely marked least terns during 2009-14. Since least terns have been documented renesting in other Great Plains populations (Toy and others, 2016, unpublished data, U. S. Geological Survey) and California least terns are known to renest (Massey and Atwood, 1981), it is likely that least terns renest, but not enough uniquely marked individuals have been monitored over a sufficiently long enough period to document these events. However, 15 percent of the nests initiated by uniquely marked plovers were renests. Close to one-half (47 percent) were actually initiated after the first nest was considered to have hatched. Renesting in least terns has primarily been reported following nest loss during early or mid-incubation (Claassen and others, 2014). There was a high degree of variability in the number of days between the fating of a nest and the initiation of a renest ( 7.5 days \pm 7.3 days). This is consistent with the results of Claassen and others, (2014), who reported a relatively short interval when nests were lost immediately following initiation (approximately 4 days) but longer when nests were lost during mid-incubation (approximately 8 days).

\section{Migratory, Winter, and other non-Central Platte River Valley Resightings of Piping Plovers}

The banding program in the Central Platte River Valley is successful in providing understanding of linkages between the Central Platte River Valley and other breeding and wintering areas. Although a bird may carry a marker that was applied on a given unit of habitat, it would be inaccurate to assume that bird will remain associated with the same habitat unit or subpopulation for the remainder of its life. The results reported here illustrate the diversity of breeding locations where birds originally banded on the Central Platte have been observed (four river systems in Nebraska and three reservoirs in Nebraska, South Dakota, and Colorado; locations not shown). Other than during the catastrophic Missouri River flood year of 2011, breeding season resightings outside of the Central Platte River Valley were estimated to constitute 5-15 percent of the banded population of piping plovers in the Central Platte River Valley in any given year. This is not a trivial percentage, although it is unknown to what extent these birds supplement breeding populations in other areas. Several of these sightings are from areas where information on demographic rates and movements is lacking (John Martin Reservoir, Lake McConaughy, Loup River, Niobrara River; locations not shown).

Resighting data from this study also suggest that birds from other breeding populations immigrate into the Central Platte River Valley, although these immigration rates are more difficult to estimate. Based on information reported here, known source populations for birds seen on the Central Platte include the Missouri River and the Lower Platte River. Other source populations also may be represented but cannot be conclusively determined because the birds were banded on the wintering grounds. Nonetheless, the resighting data indicate that there is nontrivial exchange of breeding birds between the Central Platte River Valley and several other areas within the southern part of the midcontinent breeding range.

\section{Information Needs}

The Platte River Recovery Implementation Program's stated objectives indicate that measures of reproductive success, dispersal, colonization rate of habitats by local and immigrant birds, and renesting patterns of adults are key to evaluating management actions and making future decisions about implementation. The current (2015) research program is consistent with these information needs and has provided new insight into connections between units of Central Platte River 
Valley habitat as well as connections between the Central Platte River Valley and other habitat areas.

Several metrics of ongoing importance appear when reflecting on PRRIP's objectives and the data outputs from the productivity research program. Counts of fledging-age chicks can be used to indicate productivity, but counts of unmarked birds can be inaccurate because of movements, double-counting, and other issues. An approach using individually marked young chicks and mark-resight techniques can estimate detection probability and survival rate, leading to more accurate estimates of the number of fledged young produced. Because this approach is dependent on having marked young, it also indicates the importance of a nest monitoring approach that provides an ability to count and band newly hatched young.

The number of breeding adult birds is an important metric for use in understanding the future viability of the population. Breeding population size can be estimated from nest monitoring data, following some basic assumptions about nest chronology, renesting patterns, and the conditions in which an active nest represents a breeding pair of adults. Supplementing a rigorous nest monitoring program with adult mark-resight work can provide additional insight into breeding populations and also can inform other closely related demographic processes. For example, colonization rates, dispersal patterns, and the roles of local birds compared to emigrant and immigrant birds are important metrics that can be best achieved through mark-resight work.

In addition to understanding demographic processes of least terns and piping plovers in the Central Platte River Valley, it is clear that the members of PRRIP are interested in information on how the bird populations interact with populations in other parts of the breeding range. There is reasonably complete information on the general breeding range of piping plovers in the northern Great Plains, but little information on how the various breeding areas are interconnected. In short, there is little certainty whether the system operates as a series of independent breeding populations or as one large exchanging metapopulation. Preliminary data from this study suggest there is substantial connectivity between breeding population units in the southern part of the range, but there is little indication that the northern and southern ranges are strongly connected. Continuation of mark-resight work on the Central Platte River Valley in concert with work on other breeding areas would enable these relations to be better understood.

Continued mark-resight work with least tern and piping plover chicks and adults on the Central Platte River Valley has many potential benefits to the science needs of PRRIP. Such benefits include synergy with ongoing efforts on other breeding areas, a greater understanding of how regional populations operate, science that supports Adaptive Management for Central Platte River Valley decision making, and measures of biological parameters that are relevant to the Program's priorities.

\section{References Cited}

Amirault-Langlais, D.-L., Imlay, T.L., and Boyne, A.W., 2014, Dispersal patterns suggest two breeding populations of piping plovers in eastern Canada: The Wilson Journal of Ornithology, v. 126, no. 2, p. 352-359.

Baasch, D.M., 2014, Platte River Recovery Implementation Program - 2012 and 2013 interior least tern and piping plovers monitoring and research report for the Central Platte River, Nebraska: Kearney, Nebraska, Platte River Recovery Implementation Program, 53 p.

Bivand, R.S., Pebesma, E., and Gomez-Rubio, V., 2013, Applied spatial data analysis with R ( $2 \mathrm{~d}$ ed.): Springer, N.Y. [Also available at http://www.asdar-book.org/.]

Brown, M.B., Dinan, L.R., and Jorgensen, J.G., 2014, 2014 Interior least tern and piping plover monitoring, research, management, and outreach report for the Lower Platte River, Nebraska: Lincoln, Nebr., Joint report of the Tern and Plover Conservation Partnership and the Nongame Bird Program of the Nebraska Game and Parks Commission, $44 \mathrm{p}$.

Brown, M.B., Jorgensen, J.G., and Dinan, L.R., 2009, 2009 Interior least tern and piping plover Monitoring, Research, Management, and Outreach Report for the Lower Platte River, Nebraska: Lincoln, Nebr., Joint report of the Tern and Plover Conservation Partnership and the Nongame Bird Program at the Nebraska Game and Parks Commission, $77 \mathrm{p}$.

Brown, M.B., Jorgensen, J.G., and Dinan, L.R., 2010, 2010 Interior least tern and piping plover Monitoring, Research, Management, and Outreach Report for the Lower Platte River, Nebraska: Lincoln, Nebr., Joint report of the Tern and Plover Conservation Partnership and the Nongame Bird Program at the Nebraska Game and Parks Commission, $70 \mathrm{p}$.

Brown, M.B., Jorgensen, J.G., and Dinan, L.R., 2011, 2011 Interior least tern and piping plover Monitoring, Research, Management, and Outreach Report for the Lower Platte River, Nebraska: Lincoln, Nebr., Joint report of the Tern and Plover Conservation Partnership and the Nongame Bird Program at the Nebraska Game and Parks Commission, $51 \mathrm{p}$.

Brown, M.B., Jorgensen, J.G., and Dinan, L.R., 2012, 2012 Interior least tern and piping plover Monitoring, Research, Management, and Outreach Report for the Lower Platte River, Nebraska: Lincoln, Nebr., Joint report of the Tern and Plover Conservation Partnership and the Nongame Bird Program at the Nebraska Game and Parks Commission, $48 \mathrm{p}$. 
Brown, M.B., Jorgensen, J.G., and Dinan, L.R., 2013, 2013 Interior least tern and piping plover Monitoring, Research, Management, and Outreach Report for the Lower Platte River, Nebraska: Lincoln, Nebr., Joint report of the Tern and Plover Conservation Partnership and the Nongame Bird Program at the Nebraska Game and Parks Commission, $54 \mathrm{p}$.

Catlin, D.H., 2009, Population dynamics of piping plovers (Charadrius melodus) on the Missouri River: Virginia Polytechnic Institute and State University, doctoral dissertation, $93 \mathrm{p}$.

Catlin, D.H., Felio, J.H., and Fraser, J.D., 2013, Effects of water discharge on fledging time, growth, and survival of piping plovers on the Missouri River: The Journal of Wildlife Management, v. 77, p. 525-533.

Catlin, D.H., Fraser, J.D., Felio, J.H., and Cohen, J.B., 2011, Piping plover habitat selection and nest success on natural, managed, and engineered sandbars: The Journal of Wildlife Management, v. 75, p. 305-310.

Catlin, D.H., Milenkaya, O., Hunt, K.L., Friedrich, M.J., and Fraser, J.D., 2014, Can river management improve the piping plover's long-term survival on the Missouri River?: Biological Conservation, v. 180, p. 196-205.

Claassen, A.H., Arnold, T.W., Roche, E.A., Saunders, S.P., and Cuthbert, F.J., 2014, Factors influencing nest survival and renesting by piping plovers in the Great Lakes region: The Condor, v. 116, p. 394-407.

Currier, P.J., 1997, Woody vegetation expansion and continuing declines in open channel habitat on the Platte River in Nebraska, North American Crane Workshop Proceedings: Paper 210, p. 141-152.

Dugger, K.M., Ryan, M.R., and Renken, R.B., 2000, Least tern chick survival on the lower Mississippi River: Journal of Field Ornithology, v. 71, p. 330-338.

Eschner, T.R., Hadley, R.F., and Crowley, K.D., 1983, Hydrologic and morphologic changes in channels of the Platte River Basin in Colorado, Wyoming and Nebraska-A historical perspective: U.S. Geological Survey Professional Paper 1277, $297 \mathrm{p}$.

Executive Director's Office, 2015, Platte River Recovery Implementation Program data synthesis compilation-Interior least tern (Sterna antillarum athalassos) and piping plover (Charadrius melodus) habitat synthesis chapters: Platte River Recovery Implementation Program, 269 p. [Also available at https://www.platteriverprogram.org/PubsAndData/ProgramLibrary/FINAL March 172015 PRRIP Least Tern and Piping Plover Data Synthesis Compilation.pdf.]
Faanes, C.A., 1983, Aspects of the nesting ecology of least terns and piping plovers in central Nebraska: Prairie Naturalist, v. 15 , p. $145-154$.

Grant, T.A., Shaffer, T.L., Madden, E.M., and Pietz, P.J., 2005, Time-specific variation in passerine nest survival- New insights into old questions: Auk, v. 122, p. 661-672.

Haig, S.M., and Elliott-Smith, E., 2004, Piping plover-The Birds of North America (A. Poole ed.): Ithaca, N.Y., Cornell Laboratory of Ornithology Web site accessed January 7 , 2016, at http://bna.birds.cornell.edu/bna/species/002.

Haig, S.M., and Oring, L.W., 1988, Distribution and dispersal in the Piping Plover: The Auk, v. 105, p. 630-638.

Hill, L.A., and Talent, L.G., 1990, Effects of capture, handling, banding, and radio-marking on breeding least terns and snowy plovers: Journal of Field Ornithology, v. 61, p. 310-319.

Hunt, K.L., Catlin, D.H., Felio, J.H., and Fraser, J.D., 2013, Effect of capture frequency on the survival of piping plover chicks: Journal of Field Ornithology, v. 84, p. 299-303.

Jenniges, J.J., and Plettner, R.G., 2008, Least tern nesting at human created habitats in central Nebraska: Waterbirds, v. 31, p. 274-282.

Johnson, C.W., 1994, Woodland expansion in the Platte River, Nebraska-Patterns and causes: Ecological Monographs, v. 64, p. $45-84$.

Johnson, D.H., and Shaffer, T.L., 1990, Estimating nest success - when Mayfield wins: Auk, v. 107, p. 595-600.

Kirsch, E.M., 1996, Habitat selection and productivity of least terns on the lower Platte River, Nebraska: Wildlife Monographs, no. 132, p. 5-48.

Laake, J.L., 2013, RMark-An R interface for analysis of capture-recapture data with MARK: Seattle, Washington, Alaska Fisheries Science Center, NOAA, National Marine Fisheries Service, AFSC Processed Rep 2013-01, 25 p.

LeDee, O.E., Arnold, T.W., Roche, E.A., and Cuthbert, F.J., 2010, Use of breeding and nonbreeding encounters to estimate survival and breeding-site fidelity of the piping plover at the Great Lakes: The Condor, v. 112, p. 637-643.

Massey, B.W., and Atwood, J.L., 1981, Second-wave nesting of the California Least Tern-Age composition and reproductive success: The Auk, v. 98, p. 596-605.

Massey, B.W., Bradley, D.W., and Atwood, J.L., 1992, Demography of a California least tern colony including effects of the 1982-1983 El Niño: Condor, v. 94, p. $976-983$. 
Murphy, P.J., Randle, T.J., Fotherby, L.M., and Daraio, J.A., 2004, Platte River channel-History and restoration: Denver, Colo., Bureau of Reclamation, 177 p.

Pebesma, E.J., and Bivand, R.S., 2005, Classes and methods for spatial data in R. R News 5: R News, p. 9-13. [Also available at http://cran.r-project.org/doc/Rnews/.]

Pitts, T., 1988, Status of the interior least tern and piping plover in Nebraska (period of record through 1986): Interstate Task Force on Endangered Species.

Platte River Recovery Implementation Program (PRRIP), 2014, Adaptive management on the Platte River: Kearney, Nebraska, Platte River Recovery Implementation Program Adaptive Management Plan (AMP) and 2013 "State of the Platte" Report, 91 p.

R Core Team, 2014, R-A language and environment for statistical computing: Vienna, Austria, R Foundation for Statistical Computing Web page, accessed November 11, 2015, at http://www.R-project.org/.

Renken, R.B., and Smith, J.W., 1995a, Interior least tern site fidelity and dispersal: Colonial Waterbirds, v. 18, p. 193-198.

Renken, R.B., and Smith, J.W., 1995b, Annual adult survival of interior least terns (Superviviencia Anual de Sterna antillarum en Mississippi): Journal of Field Ornithology, v. 66, p. 112-116.

Rioux, S., Amirault $\square$ Langlais, D.L., and Shaffer, F., 2011, Piping plovers make decisions regarding dispersal based on personal and public information in a variable coastal ecosystem: Journal of Field Ornithology, v. 82, p. 32-43.

Roche, E.A., Gratto-Trevor, C.L., Goossen, J.P., and White, C.L., 2012, Flooding affects dispersal decisions in piping plovers (Charadrius melodus) in prairie Canada: The Auk, 129, p. 296-306.

Roche, E.A., Shaffer, T.L., Anteau, M.J., Sherfy, M.H., Stucker, J.H., Wiltermuth, M.T., and Dovichin, C.M., 2014, Detection probability of least tern and piping plover chicks in a large river system: Journal of Wildlife Management, v. 78, p. 709-720.

Saunders, S.P., Arnold, T.W., Roche, E.A., and Cuthbert, F.J., 2014, Age-specific survival and recruitment of piping plovers Charadrius melodus in the Great Lakes region: Journal of Avian Biology, v. 45, p. 437-449.

Schumm, S.A., 2005, River variability and complexity: New York, Cambridge University Press, p. 135.
Schweitzer, S.H., and Leslie, D.M., Jr., 2000, Stage-specific survival rates of the endangered least tern (Sterna antillarum) in northwestern Oklahoma (2d): Springer, N.Y., Proceedings of the Oklahoma Academy of Science, v. 80, p. 53-60. [Also available at http://www.asdar-book.org/.]

Shaffer, T.L., 2004, A unified approach to analyzing nest success: The Auk, v. 121, p. 526-540.

Shaffer, T.L., Sherfy, M.H., Anteau, M.J., Stucker, J.H., Sovada, M.A., Roche, E.A., Wiltermuth, M.T., Buhl, T.K., and Dovichin, C.M., 2013, Accuracy of the Missouri River least tern and piping plover monitoring program - Considerations for the future: U.S. Geological Survey Open-File Report 2013-1176, 91 p.

Sherfy, M.H., Anteau, M.J., Shaffer, T.L., Sovada, M.A., and Stucker, J.H., 2012a, Foraging ecology of least terns and piping plovers nesting on Central Platte River sandpits and sandbars: U.S. Geological Survey Open-File Report 2012-1059, 50 p.

Sherfy, M.H., Stucker, J.H., and Buhl, D.A., 2012b, Selection of nest-site habitat by interior least terns in relation to sandbar construction: Journal of Wildlife Management, v. 76, p. 363-371.

Sidle, J.G., and Kirsch, E.M., 1993, Least tern and piping plover nesting at sand pits in Nebraska: Colonial Waterbirds, v. 16 , p. 139-148.

Simons and Associates, Inc., and U. R. S. Greiner Woodward Clyde, 2000, Physical history of the Platte River in Nebraska-Focusing upon flow, sediment transport, geomorphology, and vegetation: Simons and Associates, Inc., $100 \mathrm{p}$.

Stucker, J.H., Buhl, D.A., and Sherfy, M.H., 2013, Consequences of least tern (Sternula antillarum) microhabitat nest-site selection on natural and mechanically constructed sandbars in the Missouri River: The Auk ,v. 130, p. 753-763.

Thompson, B.C., Jackson, J.A., Burger, J., Hill, L.A., Kirsch, E.M., and Atwood, J.L., 1997, Least tern (Sterna antillarum) in The Birds of North America, No. 290 (A. Poole and F. Gill, eds.): The Academy of Natural Sciences, Philadelphia, Pa., and The American Ornithologists' Union, Washington, D.C., 32 p.

White, G.C., and Burnham, K.P., 1999, Program MARKSurvival estimation from populations of marked animals: Bird Study, v. 46, p. S1, S120-S139.

Williams, G.P., 1978, The case of the shrinking channels-The North Platte and Platte Rivers in Nebraska: U.S. Geological Survey Circular 781, p. 48.

Wycoff, R.S., 1960, The least tern: Nebraska Bird Review, v. 28 , p. $39-42$. 
Publishing support provided by: Rolla Publishing Service Center

For more information concerning this publication, contact: Director, USGS Northern Prairie Wildlife Research Center 8711 37th Street Southeast

Jamestown, North Dakota 58401

(701) 253-5553

Or visit the Northern Prairie Wildlife Research Center Web site at: http://www.npwrc.usgs.gov/ 

를

흘

产

$\stackrel{ }{r}$

5

$\stackrel{9}{9}$

急

言

후․

끌

毘.

完

刃

롱

훙

刃্乛ে

\$્థ

交

욤

获

! 욕

옹

$\frac{1}{\circ}$ 